
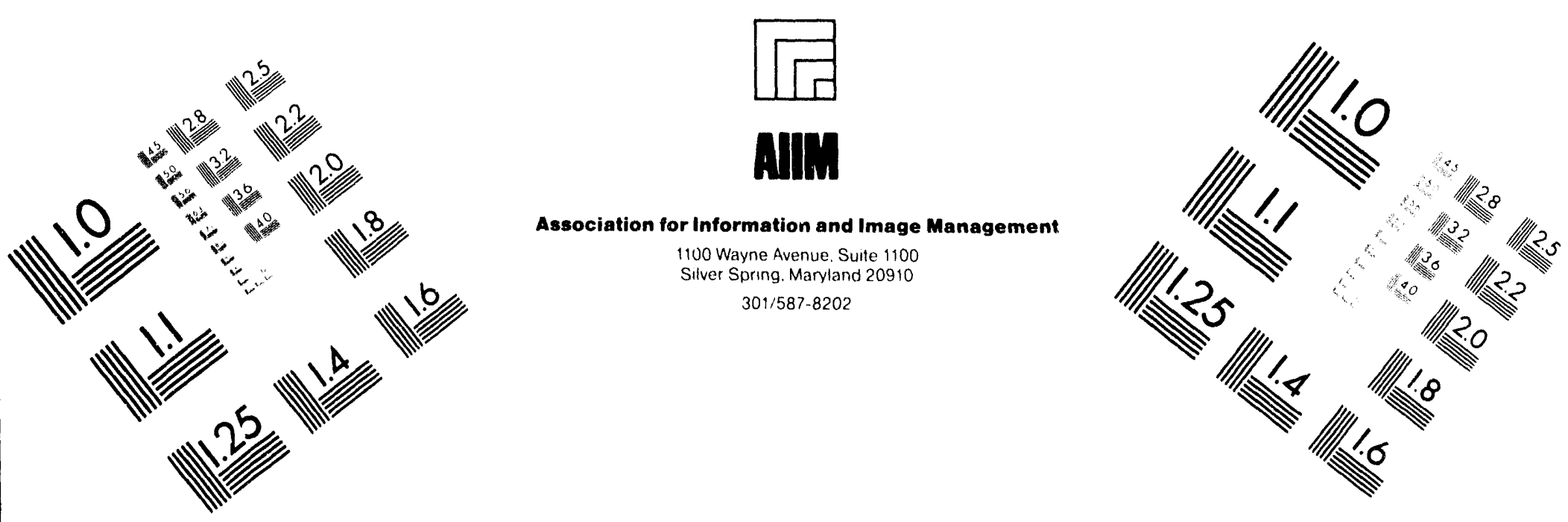

\title{
Centimeter
}

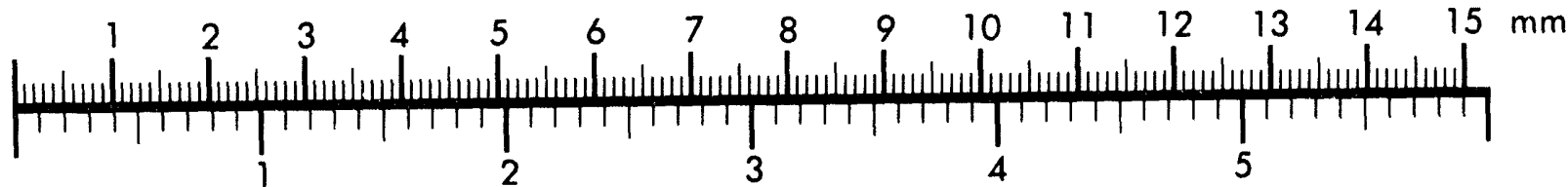

Inches
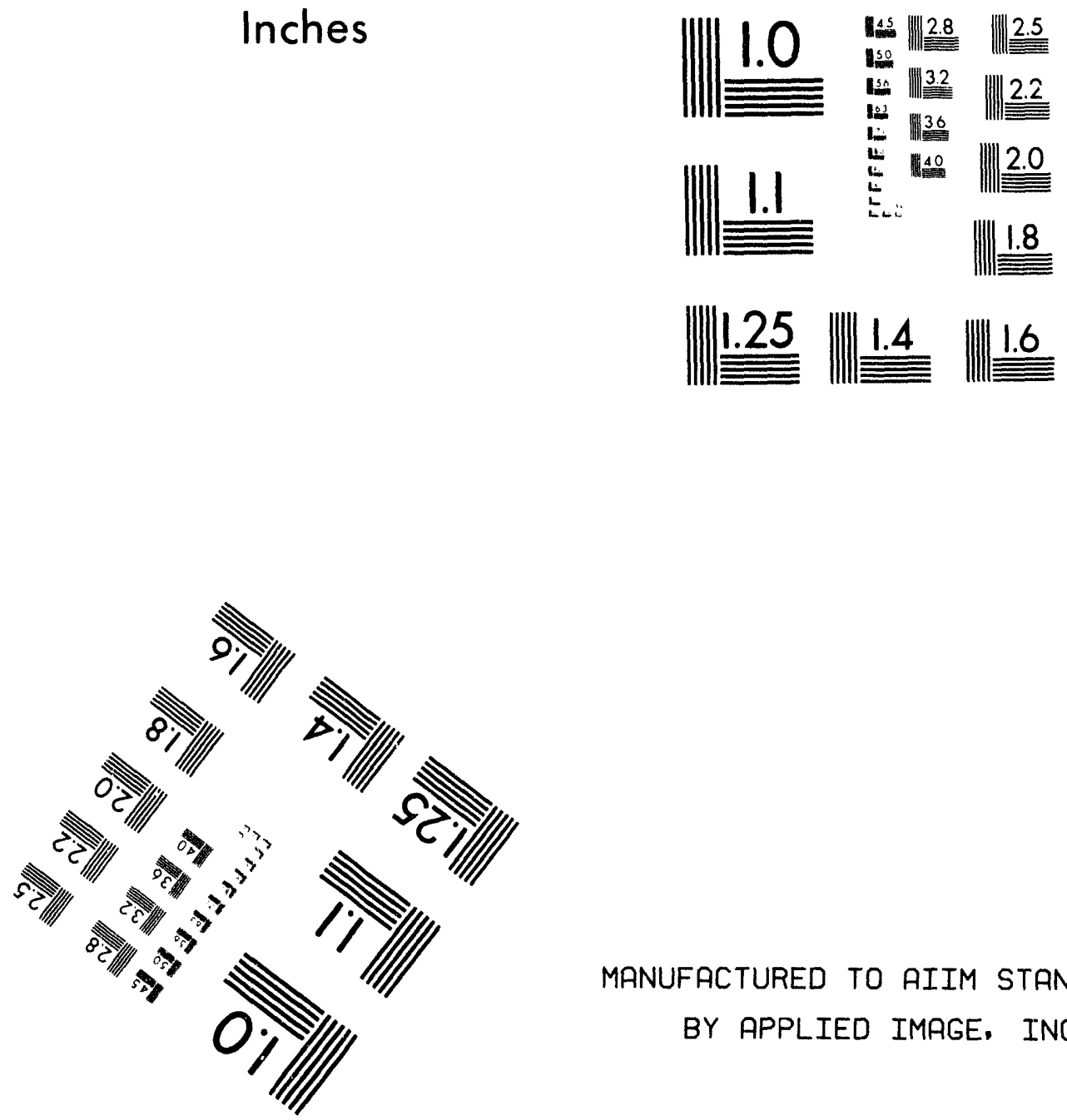

MANUFACTURED TO AIIM STANDARDS BY APPLIED IMRGE, INC.

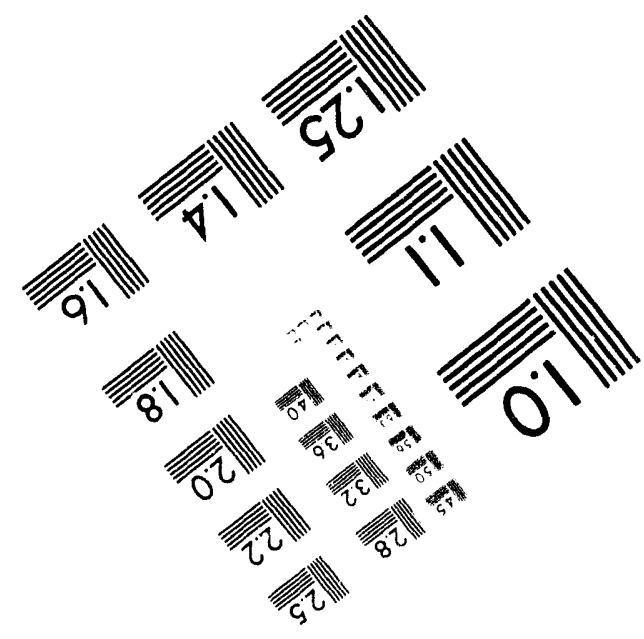



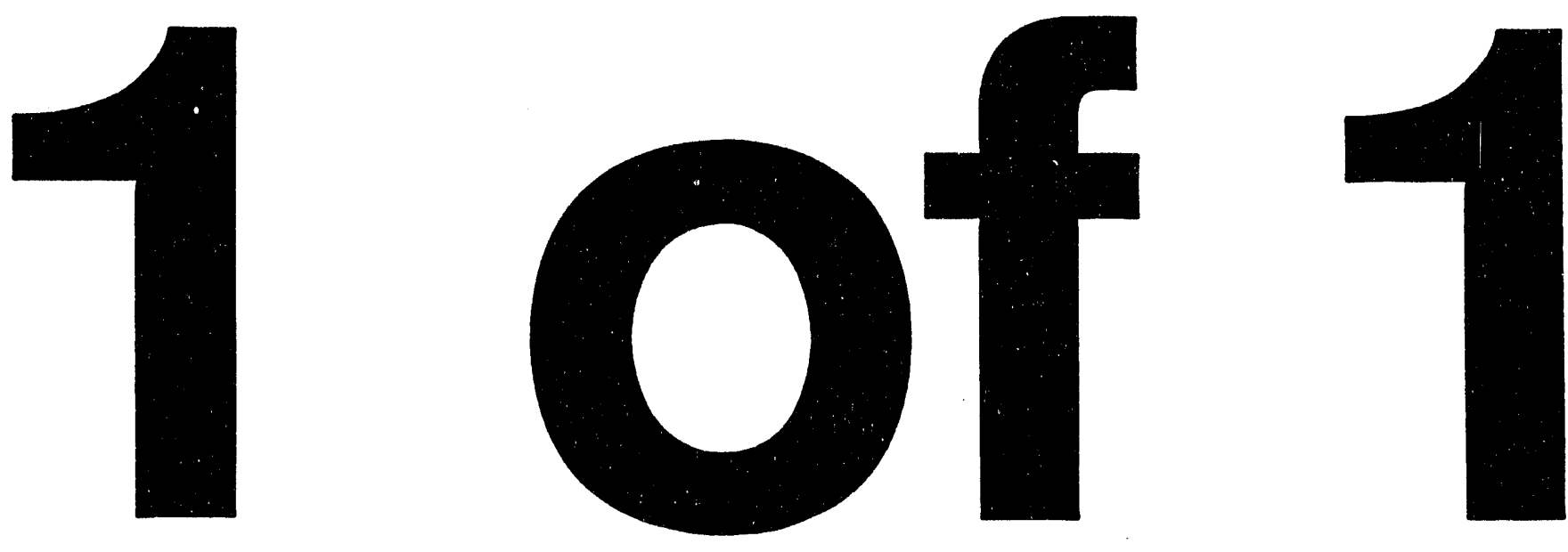


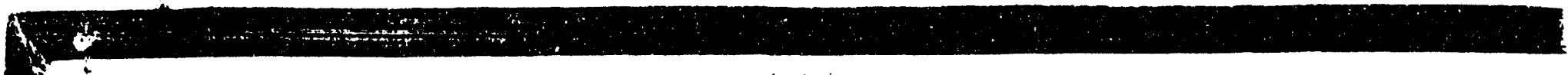

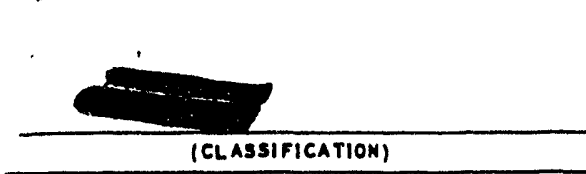

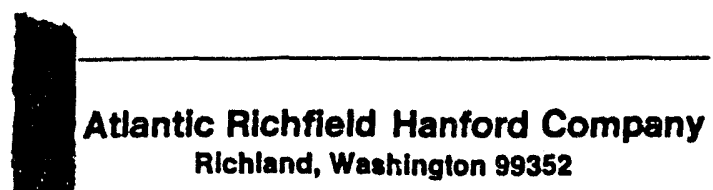

Richland, Washington 99352
PAOJECT

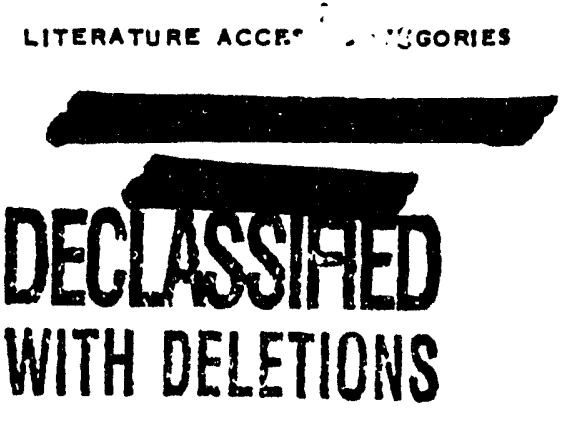

Literature ACCFe'

ISSUING FILE

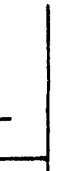

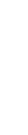
WITH DELETIONS
TITLE AND AUTHOR
DOCUMENT NO.

ARH-2585 - DEL.

SERIES AND COPY NO.

A

$$
2
$$

DATE

August 23, 1972

STUDY (IV)
UTILIZATION OF Z PLANT MECIVIFD
FOR PLOWSHARE PROGRAM MAY 271994
L. E. Bruns

ThIS T-MUT MUST NOT BE LEFT UNATTENDED OR WHERE AN UNAUTHOWI USON MAY HAVE ACCESS TO IT. WHEN NOT IN

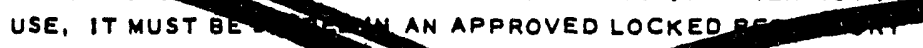
WITHIN AN APPROVED W AREA. MINTIS IN YOUR POSSESSION AND UNTIL YOO OUR WREO IT TO YOUR CLASSIFIED DOCUMENT RS TUTATION, IT IS YOUR RESPONSIBILITY TO TIT ANO ITS DUTS WITHIN THE LIMITS OF THM SSCT ANO FROM ANY UNAUT ISEP PERSON. ITS TM NTAL TO, AND STORAGE AT YOUR M TOE RE WCE IS PROHIBITED. IT WILL BE OUPLICATEDO A.CORDANCE WITH EXISTING SECURITY REGULATIONS. AL. PERSONS READING THIS DOCUMENT ARE REQUESTED TO SIGN

IN THE SPACE BELOW.

UNAUTHORIZED DISCLOSURE SUBJECT TO CRIMINAL SANCTIONS.

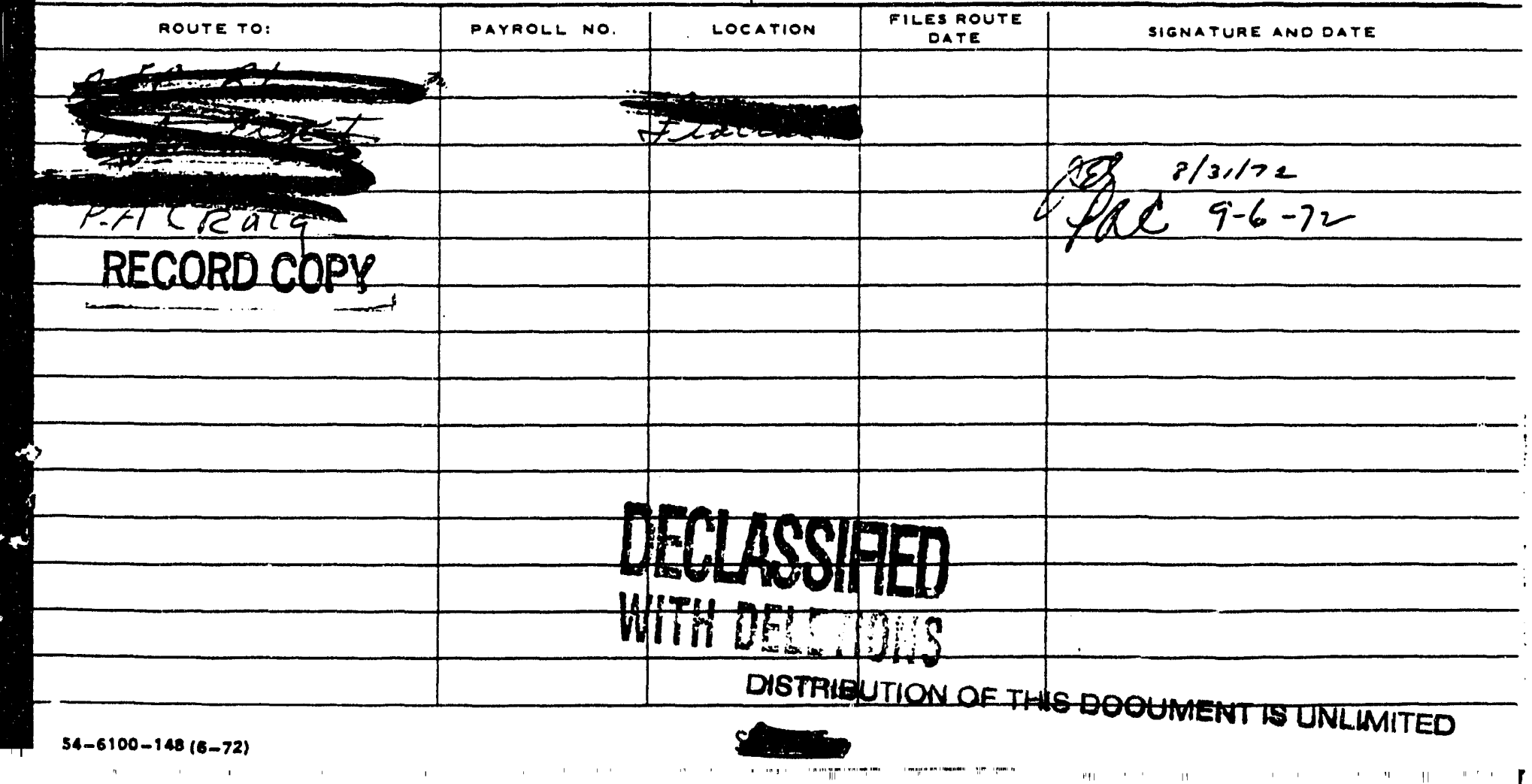



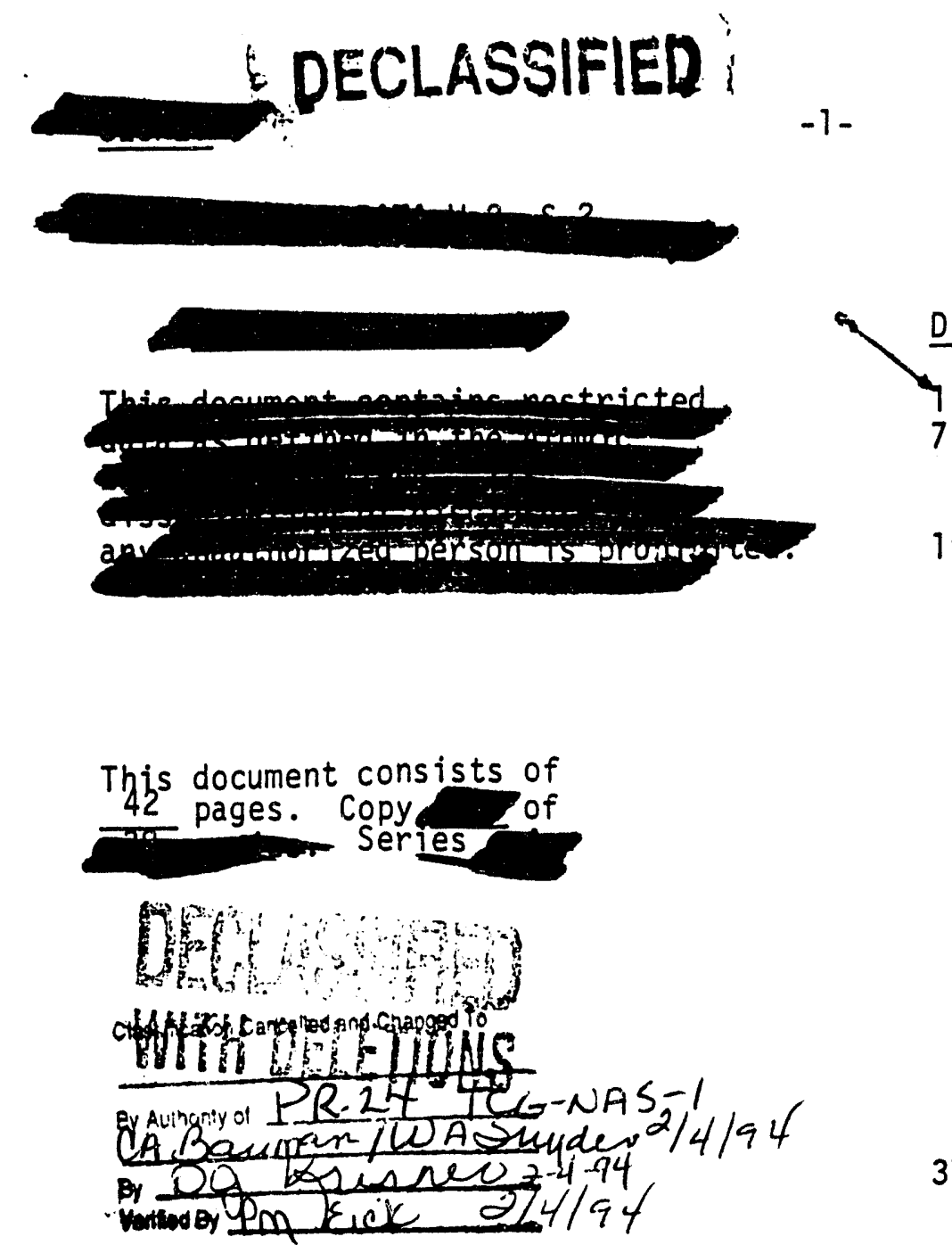

Distribution:

- 6. 0. J. Elgert, AEC-RL

7 -16. W. J. Hogan, LLL

17. L. I. Brecke

18. L. E. Bruns

19-20. Phyllis Daly, AEC-HQ

21. I. L. Williams, AECOP

22. R. P. Corlew

23. B. M. Dobbs

24. J. B. Fecht

25. H. H. Hopkins, Jr.

26. W. P. Ingalls

27. R. D. Jensen

28. L. M. Knights

29. L. M. Richards

30. J. M. Schultz

31. H. P. Shaw

32. A. E. Smith

33. P. W. Smith

34. J. H. Warren

35. R. R. King, PNL

36. L. G. Faust, PNL

37-38. ARHCO Files

\title{
STUDY (IV)
}

UTILIZATION OF Z PLANT

FOR PLOWSHARE PROGRAM

\section{E. Bruns}

\author{
Plutonium Process Engineering Section \\ Operations Support Engineering Department
}

\author{
ATLANTIC RICHFIELD HANFORD COMPANY \\ Richland, Washington
}

\section{DISCLAIMER August 23, 1972}

This report was prepared as an account of work sponsored by an agency of the United States Government. Neither the United States Government nor any agency thereof, nor any of their employees, makes any warranty, express or implied, or assumes any legal liability or responsibility for the accuracy, completeness, or usefulness of any information, apparatus, product, or process disclosed, or represents that its use would not infringe privately owned rights. Reference herein to any specific commercial product, process, or service by trade name, trademark, manufacturer, or otherwise does not necessarily constitute or imply its endorsement, recommendation, or favoring by the United States Government or any agency thereof. The views and opinions of authors expressed herein do not necessarily state or reflect those of the United States Government or any agency thereof. 


\section{TABLE OF CONTENTS}

\begin{tabular}{|c|c|c|}
\hline & & Page No. \\
\hline \multicolumn{2}{|l|}{ INTRODUCTION } & 3 \\
\hline \multicolumn{2}{|l|}{ CASES } & 3 \\
\hline \multicolumn{2}{|l|}{ Table I } & 3 \\
\hline \multicolumn{2}{|c|}{ OUTPUTS AND THROUGHPUTS } & 3 \\
\hline Table II & $\begin{array}{l}\text { Lower Rate Output and Throughput } \\
\text { Requirements }\end{array}$ & 4 \\
\hline Table III & $\begin{array}{l}\text { Higher Rate Output and Throughput } \\
\text { Requirements }\end{array}$ & 5 \\
\hline \multicolumn{2}{|c|}{ FACILITIES REQUIRED } & 6 \\
\hline \multicolumn{2}{|c|}{ EXISTING BUILDINGS } & 6 \\
\hline \multicolumn{2}{|c|}{ NEW BUILDING } & 7 \\
\hline \multicolumn{2}{|l|}{ COSTS } & 8 \\
\hline Table IV & $\begin{array}{l}\text { Capital Cost Estimate -- Existing } \\
\text { Building }\end{array}$ & 10 \\
\hline Table V & $\begin{array}{l}\text { Capital Cost Estimates for New } \\
\text { Facility }\end{array}$ & 11 \\
\hline Table VI' & $\begin{array}{l}\text { Capital Cost Estimates for New } \\
\text { Facility }\end{array}$ & 12 \\
\hline Table VII & Operating Costs -- Lower Rates & 13 \\
\hline Table VIII & Operating Costs -- Higher Rates & 15 \\
\hline Table IX & Unit Cost in Dollars & 17 \\
\hline \multicolumn{2}{|l|}{ FLOWSHEETS } & 18 \\
\hline \multicolumn{2}{|l|}{ RADIATION } & 19 \\
\hline \multicolumn{2}{|l|}{ ACKNOWLEDGEMENTS } & 21 \\
\hline \multicolumn{2}{|l|}{ REFERENCES } & 21 \\
\hline \multicolumn{3}{|l|}{ APPENDIX } \\
\hline Descr & Description of Existing Facility and Equipment & 22 \\
\hline Opera & Operating Experience & 25 \\
\hline Flows & Flowsheets & 26 \\
\hline
\end{tabular}




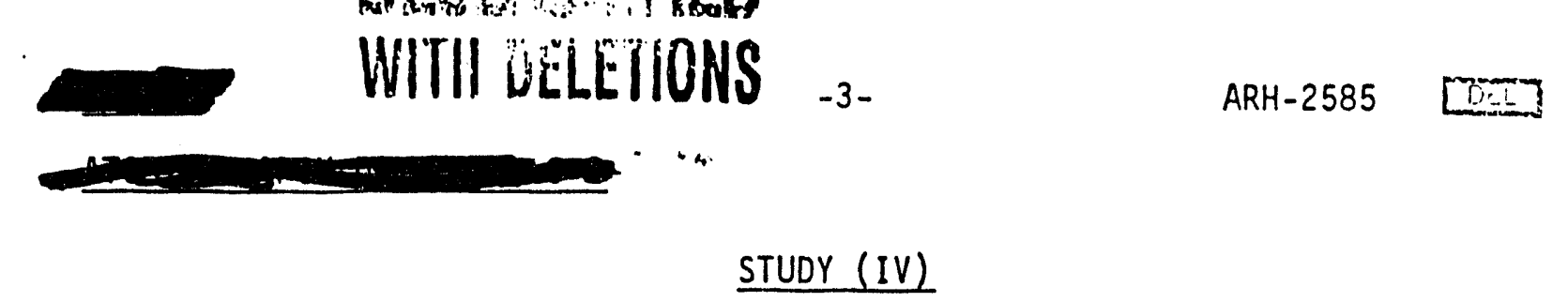

UTILIZATION OF Z PLANT

FOR PLOWSHARE PROGRAM

\section{INTRODUCTION}

The conversion of plutonium nitrate to metal, the fabrication and assembly of plutonium devices and the recovery of scrap by Atlantic Richfield Hanford Company (ARHCO) has been studied previously in support of the Plowshare Program. Previous studies (references 1,2 and 3) and Plowshare Task Force meetings (references 4 and 5 ) along with a teletype directive (reference 6) form the bases for Study IV. The major changes and additions in Study IV as compared to study III are (1) a complete new building is considered as an alternate to the use of existing facilities, (2) waste storage tankage is added to capital costs, (3) operating costs are divided into labor, material and overheads, and are based on 1976 dollars, (4) depreciation on capital costing is excluded from unit costs, and (5) features of the existing ARHCO plant coupled with comments on actual operating experience and further explanation of the flowsheets are added to the appendix.

\section{CASES}

The following table shows the type and weight of material in the four study cases:

\section{TABLE I}

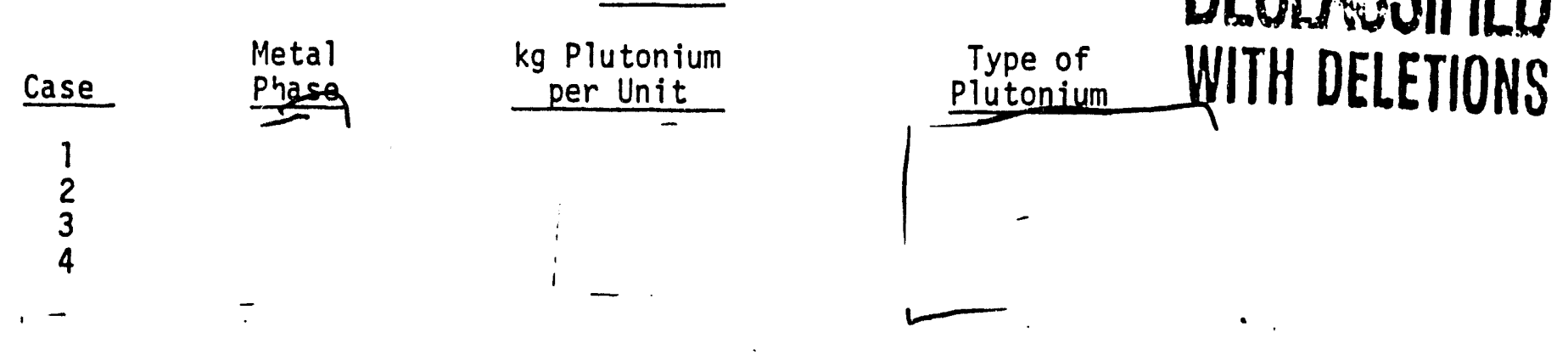

\section{OUTPUTS AND THROUGHPUTS}

Tables II and III show the outputs (amount shipped) and the throughputs (capacity of each facility to attain the required output) starting with 1978. Table II covers lower production rates; Table III covers higher rates. Not included in the tables is the total amount of plutonium that should be made available as plutonium nitrate from the fuel reprocessor to assure that shipping requirements can be met. The total amount is dependent. upon storage requirements of nitrate for blending, necessary in-process inventories. and final device storaqe. 


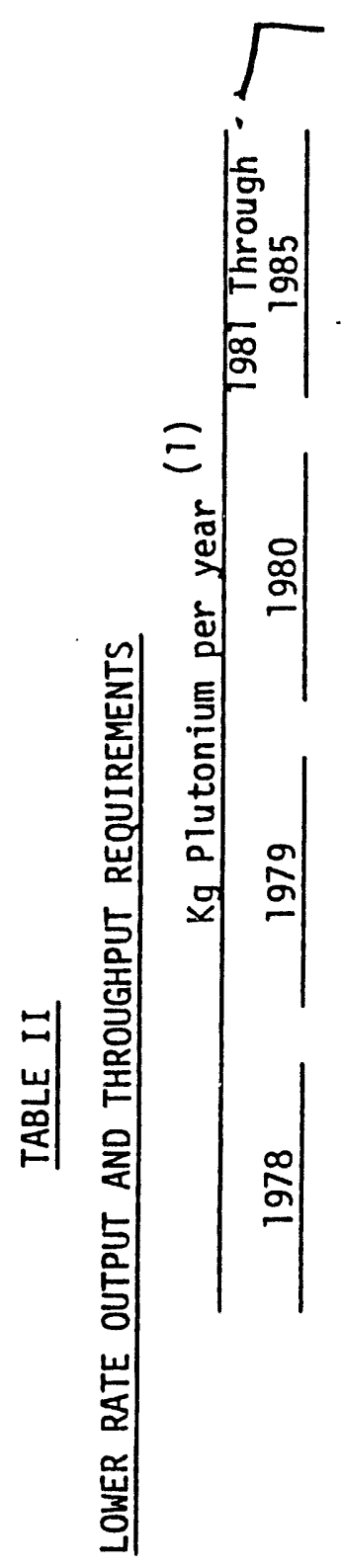

\section{+芯向 \\ 동}

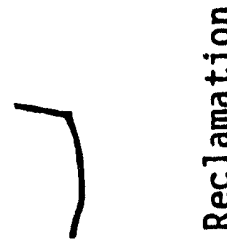

$\frac{5}{0}$

통

竞 *.

家宁

ํํㄴ

究

\& 4 के

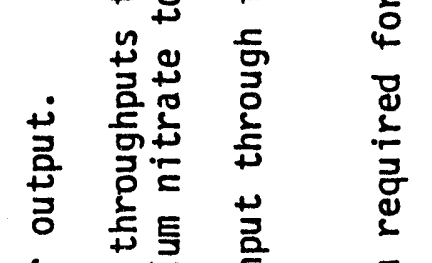

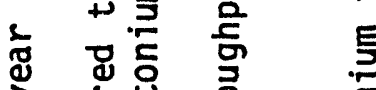

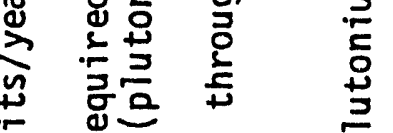

ह क व

ญ

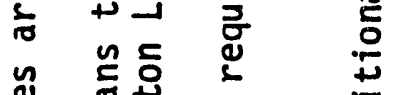

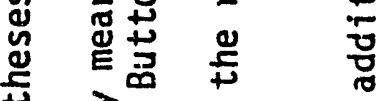

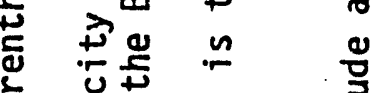

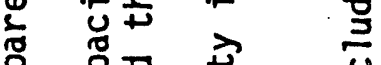

융

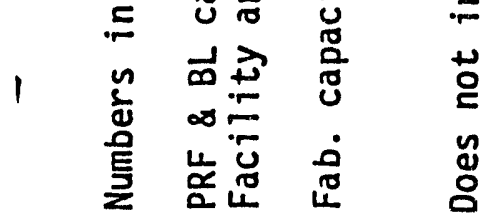

$\Xi \tilde{\Xi}$ ก

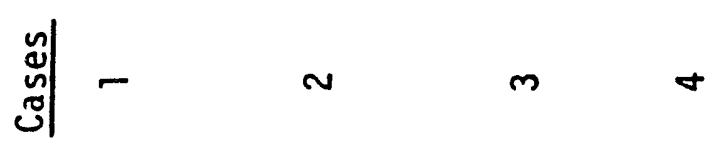

㟧 

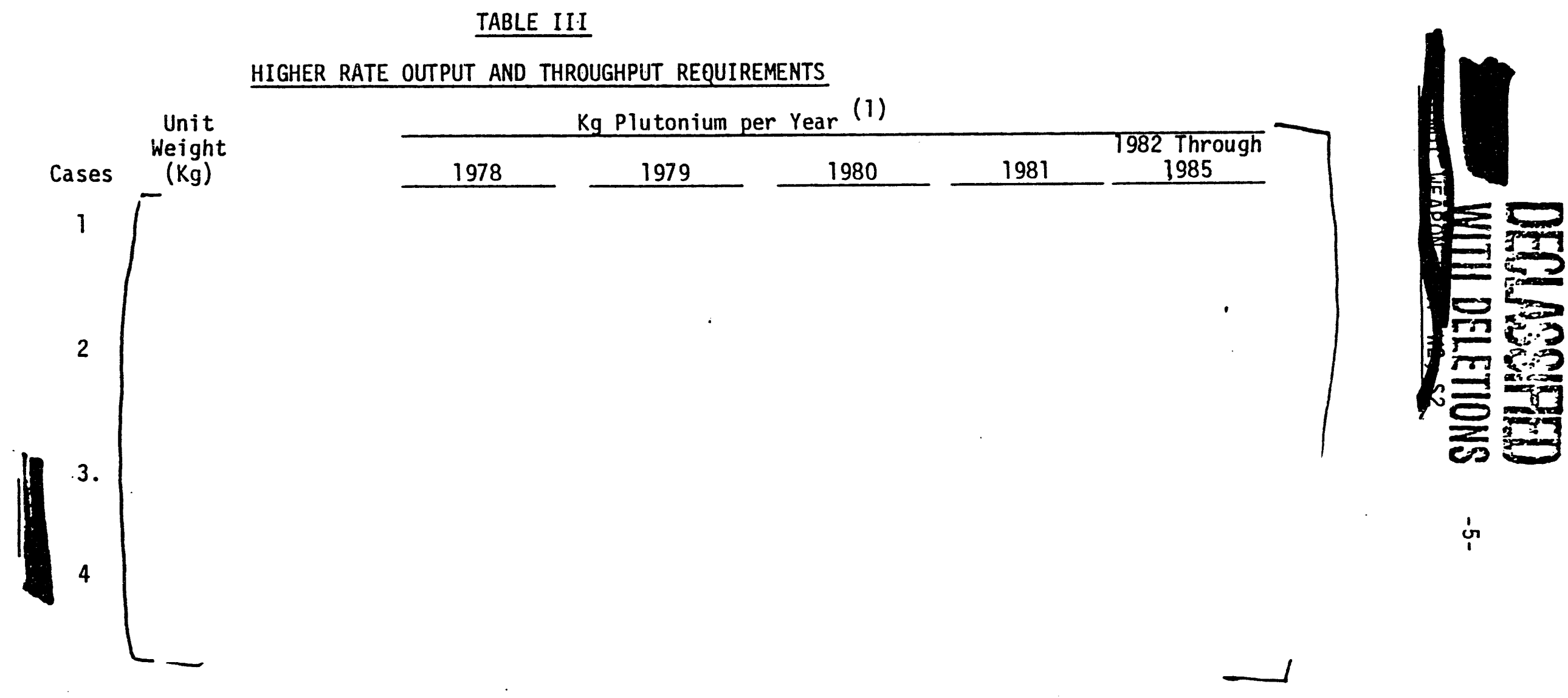

NOTES: (1) Numbers in parentheses are units/year output.

(2) PRF \& BL Cap. means the required throughputs through the Plutonium Reclamation Facility and the Button Line (plutonium nitrate to metal).*

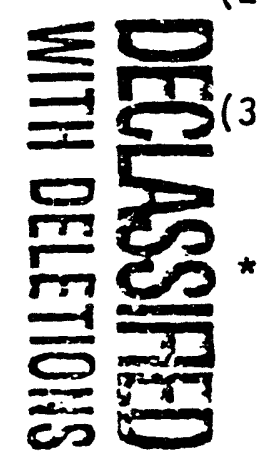

3) Fab. cap. is the required throughput through fabrication.*

Does not include additional plutonium required for lag storage. 


\section{DECLASSIFIED}

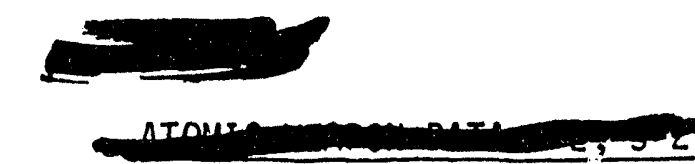

FACILITIES REQUIRED

Facilities considered for this study were 1) existing building with renovations, and 2) a complete new building with new equipment. All new buildings and equipment will meet the tornado, earthquake, radiation exposure and criticality prevention criteria.

\section{EXISTING BUILDINGS}

The existing building is a multimillion dollar complex complete with a highly efficient ventilation system. It has passed a Factory Mutual inspection for fire safety. These features and others are discussed in Appendix A.

The change and additions to existing facilities will be based on striving to attain a 1 rem per man year goal limit at the working face of processing hoods. Such a goal may not be entirely practicable for all existing equipment, but additional shielding will lower the overall exposure to personnel. In any case, the overall radiation dosage to personnel will be less than $5 \mathrm{rem} / \mathrm{man}$ year (body) and less than $30 \mathrm{rem} / \mathrm{man}$ year (hand). Shielding and equipment requirements are noted below.

\section{Case 1 and 2 Requirements (Weapon Grade Composition)}

Plutonium Reclamation Facility (PRF)

To attain a reduce exposure, additional shielding is required in the Miscellaneous Treatment hoods, access hoods, penthouse hoods, and charging hoods.

Waste Treatment Facility

Additional shielding is required in all americium processing areas. Plutonium Nitrate to Metal Process (Button Line)

Additional shielding is required in all hoods.

Fabrication

Existing hoods must be renovated and provided with better shielding. Equipment, [ and assembly hoods must be added.

General

All plutonium storage areas within the process buildings should be further shielded.
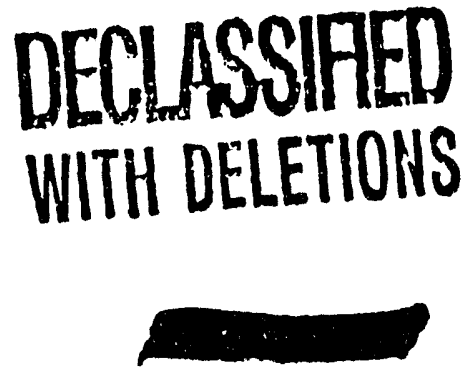
Case 3 and 4 Requirements

Plutonium Reclamation Facility (PRF)

$1-$

use existing PRF

-facilities with added shielding for Miscellaneous Treatment, access hoods, penthouse hoods, and the incinerator. Also, some equipment is required to guarantee capacities such as a product concentrator, a few hiaher capacity pumps and columns inventory control instrumentation. $b$ compact rich feed facility (see figure VII in the appendix). need Waste Treatment

Turification shielding is required. $\quad\left\{\begin{array}{l}\text { only added americium } \\ \text { the americium puri- }\end{array}\right.$ fication ex is $t$ ing equipment must be replaced with higher capacity, semiremote hoods (manipulator on one side, gloves on the other).

Plutonium Nitrate to Metal Process (Button Line)

Both cases require new blending, oxalate precipitation, calcination, fluorination, and metal reduction hoods and equipment which can be operated semiremotely. i

\section{Fabrication and Assembly}

Existing hoods and equipment must be replaced by those which can be operated semiremotely (either manipulator on one side, gloves on the other, or other $i$ sans to minimize handling). A new semiremote hood will be required for assembly.

\section{NEW BUILDING}

The new building would house all facilities for plutonium nitrate purification and scrap recovery, waste treatment and americium recovery, incineration of scrap: conversion of nitrate to metal, fabrication, final inspection, assembly and some storage. Also, the new building will contain supporting services such as laboratories and maintenance shops. The size of the building for cases I and 2 is 50,000 square feet and for cases 3 and 4 is 60,000 square feet.

are as follows: ] The design bases

Cases 1 and 2

Reclamation

Button Line Waste Treatment

Am Purification

Waste Storage Tanks

Incinerator

Fabrication

Inspection \& Assembly
$200 \mathrm{~kg} \mathrm{Pu} / \mathrm{Mo}$

$1 \mathrm{~kg} \mathrm{Pu} / \mathrm{hr}$

4000 liters neutralized waste/day

$10 \mathrm{~g} \mathrm{Am} / \mathrm{Mo}$

One, 1,000,000 gallon tank 2 drums/dav

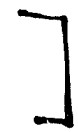

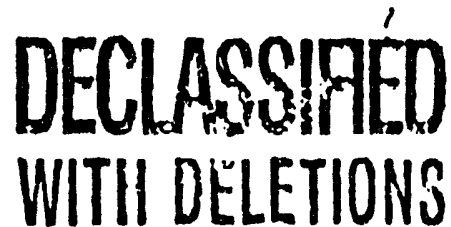

*In building, firewall protected -- alternate, separate building. 
Cases 3 and 4

Reclamation

Button Line

Waste Treatment

Am Purification

Waste Storage Tank

Incinerator

Fabrication

Inspection \& Assembly
$1200 \mathrm{~kg} \mathrm{Pu} / \mathrm{Mo}$ (800 rich, 400 lean)

$2 \mathrm{~kg} \mathrm{Pu} / \mathrm{hr}$

8000 liters neutralized waste/day

20.g Am/Day

Three, 1,000,000 gallon tanks

4 drums/day -

\section{COSTS}

Bases and Assumptions

1. Cost figures are based on 1973 dollars for capital and 1976 dollars for operating.

2. Flowsheets shown in the appendix or multiples of these (see discussion on flowsheets) are used as a basis.

3. Past experience with design and construction of similar type facilities is used for capital costing (escalated to 1973 dollars).

4. Current and past (fabrication) operating experience forms a basis for operating costs.

5. All operating costs will include full costs, i.e., manufacturing costs plus ARHCO and AEC overheads.

6. All new construction will be such that the exposure at the working face of the hood will be less than $1 \mathrm{rem} / \mathrm{man}$ year. Shielding will be added to existing hoods and plutonium storage areas even though the $1 \mathrm{rem} / \mathrm{man}$ year is difficult to attain. In all cases, the body exposure will be less than 5 rems/man year, and the hand exposure will be less than 30 rems/ man year.

7. The following average isotopic abundance [

$$
\lrcorner \text { is assumed: }
$$
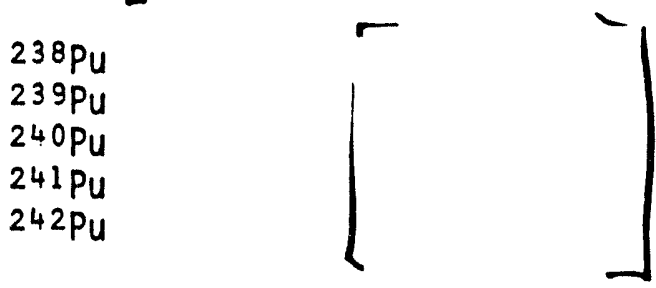

8. Weapons grade nitrate should not require americium removal. For this study, all[_ _nitrates will be processed to remove americium. 


\section{meng

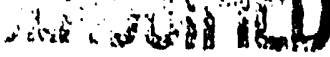 \\ WITH DELETIONS -9}

ARH -2585

9. The flowsheets will have all fabrication scrap routed back through recovery to reduce exposure levels in the nitrate to final unit processing. With weapons grade, the bulk of the fabrication metal scrap will go back to ingotting.

10. It is assumed that the existing PRF can handle

that, a compact recovery unit (see Figure VII appendix) for processing the nitrate (americium removal) and the metal rework will be added.

11. Fabrication recycle is assumed to be [] Plutonium nitrate to metal (button) is 5 percent. Plutonium losses to in-tank solidification (ITS) are less than 0.2 percent of the nitrate feed plutonium. Approximately 75 percent of the americium will be recovered; the remainder is safely stored in ITS.

12. The starting material will be about a 200 gram plutonium/liter plutonium nitrate solution in all cases.

13. Development work is assumed that will result in a minimum of rework for the plutonium metal balls [ It is

als 0 assumed that gallium can be added in the ingotting step.

14. Neither shipping costs for delivery of plutonium nitrate and oralloy to Hanford or the delivery of metal, shapes, or final units off-site are included in the costing.

15. Special tooling for fabrication is added into operating costs.

16. Assembly costs consider the primary but not the secondary assembly.

17. The possibility of cost sharing with servicing components of other programs and attendant savings was considered but not reflected in operating costs. The savings would be approximately $10 \%-25 \%$ depending on production levels and facilities employed.

\section{Capital Costs}

The capital expenditures required for the various cases shown in tables IV, V, and VI, on the following pages. Each table is followed with a timing schedule. For the new Building, design is based on the maximum capacity.

Operating Costs

Total operating costs based on 1976 dollars are given in tables VII and VIII. costs are divided into labor, material and overheads. An important factor in assuring that these costs can be met is the experience that is available at ARHCO (see AppendiX B).

Unit Costs

Table IX gives the unit costs for the various rates. 

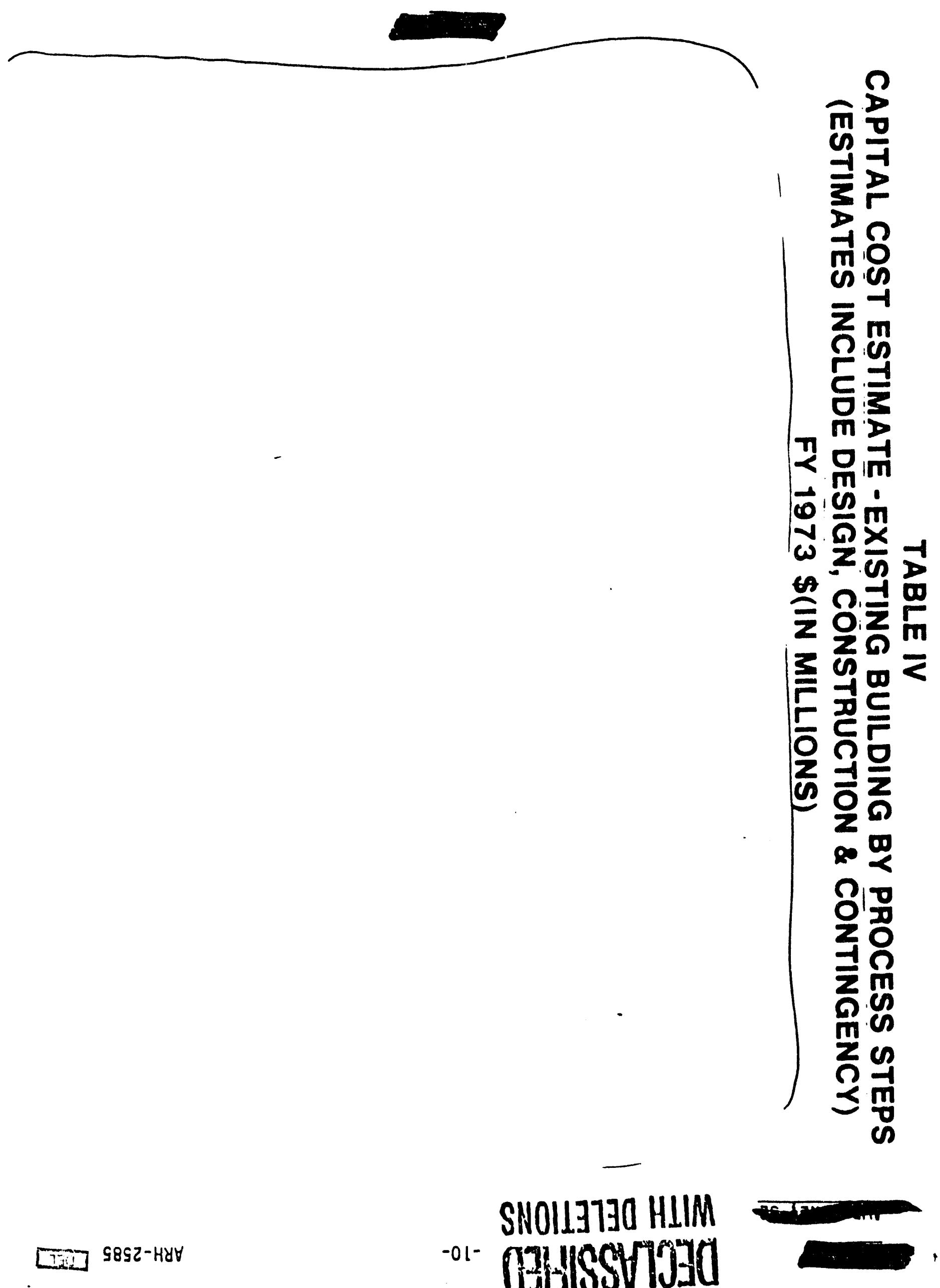


\section{TABLE V}

\section{CAPITAL COST ESTIMATES FOR NEW FACILITY}

CASES $1 \& 2[$
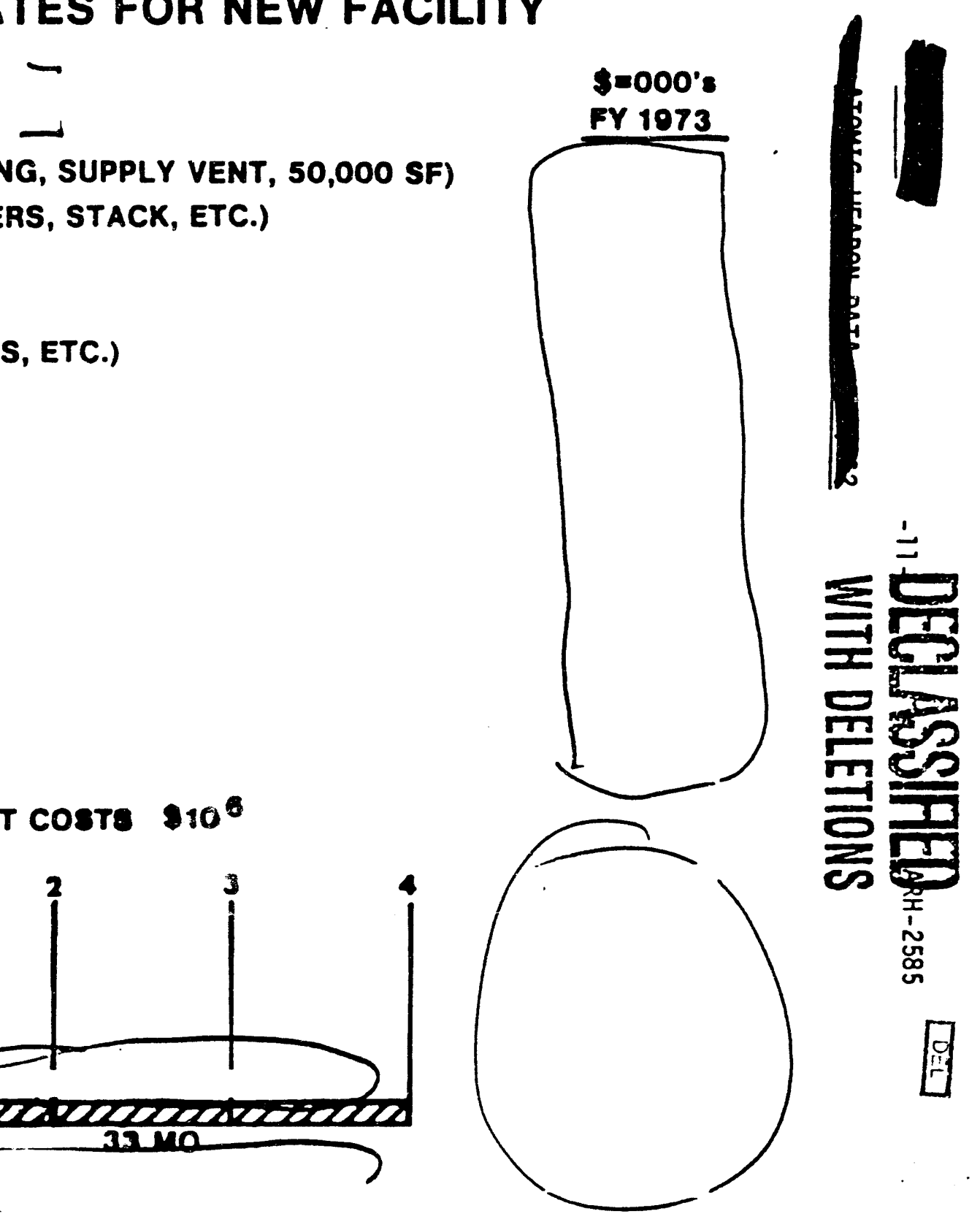

BUILDING (CONCRETE, LIGHTING, PLUMBING, SUPPLY VENT, 50,000 SF)

EXHAUST AIR SYSTEM (EQUIPMTAT, FILTERS, STACK, ETC.)

CHEMICAL MAKEUP SYSTEM

ELECTRICAL (500 KVA)

SAFEGUARDS (INTRUSION ALARMS, LOCKS, ETC.)

BUTTON LINE

FABRICATION LINE

INSPECTION

ASSEMBLY

PU RECLAMATION FACILITY

INCINERATOR

WASTE TREATMENT

WASTE STORAGE TANKS

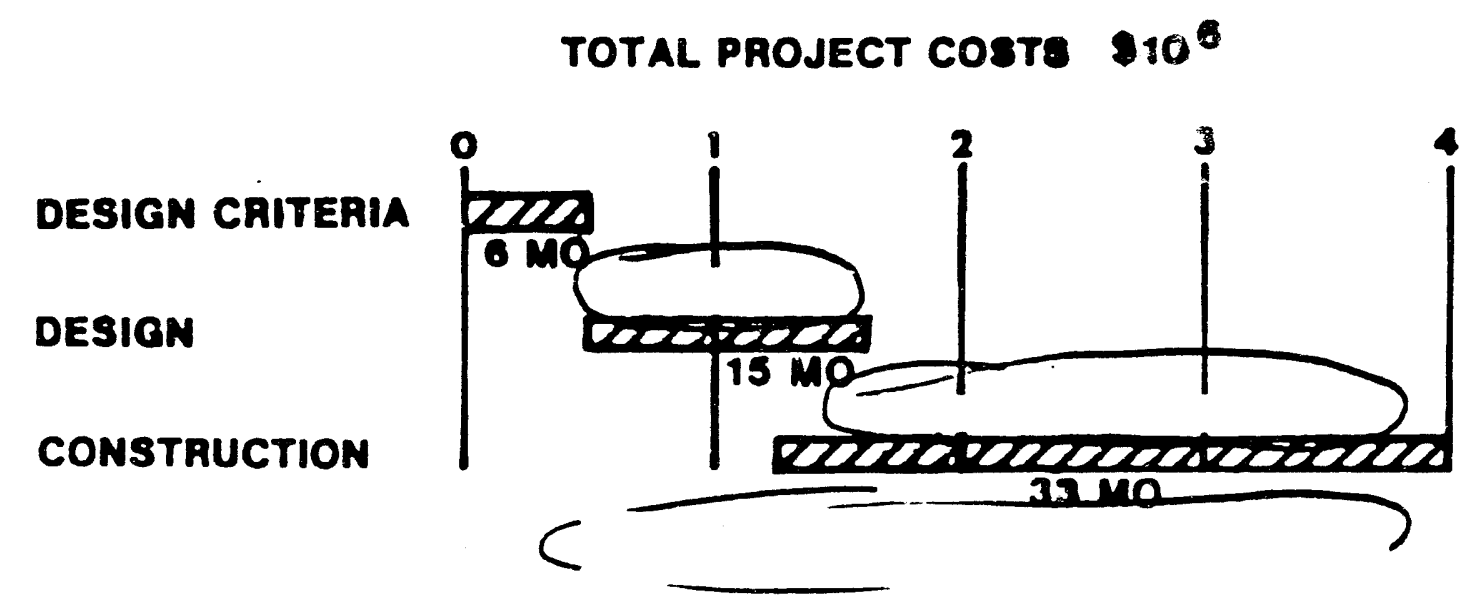




\section{TABLE VI}

\section{CAPITAL COST ESTIMATES FOR NEW FACILITY}

\section{CASES $3 \& 4\lceil$}

BUILDING - (CONCRE, C, LIGHTING, PLUMBING \& SUPPLY VENT, 60,000 SF) EXHAUST AIR SYSTEM (EQUIPMENT, FILTERS \& STACK)

CHEMICAL MAKEUP SYSTEM

ELECTRICAL (500 KVA)

SAFEGUARDS - (INTRUSION ALARMS, LOCKS, ETC.)

BUTTON LINE

FABRICATION LINE

INSPECTIŌN

ASSEMBLY

Pu REClamation

INCINERATOR

WASTE TAEATMENT - (INCLUDING AM FACILITIES)

WASTE STORAGE TANKS

TOTAL PROJECT COSTS $\$ 10^{6}$

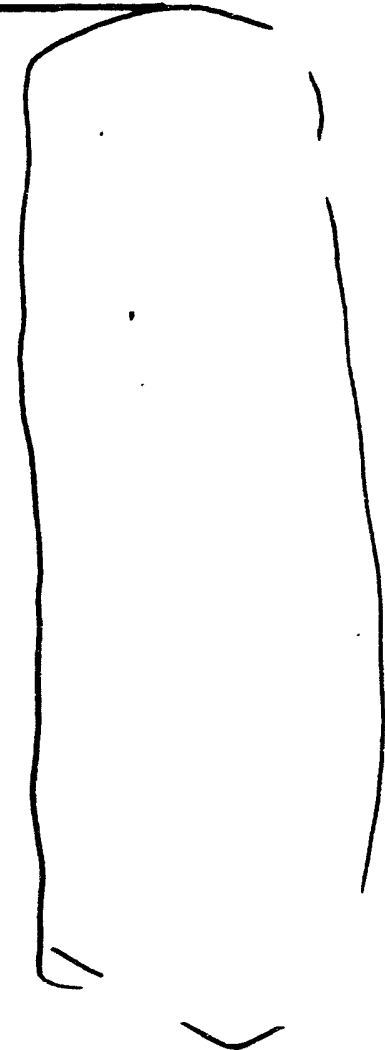

DESIGN CRITERIA
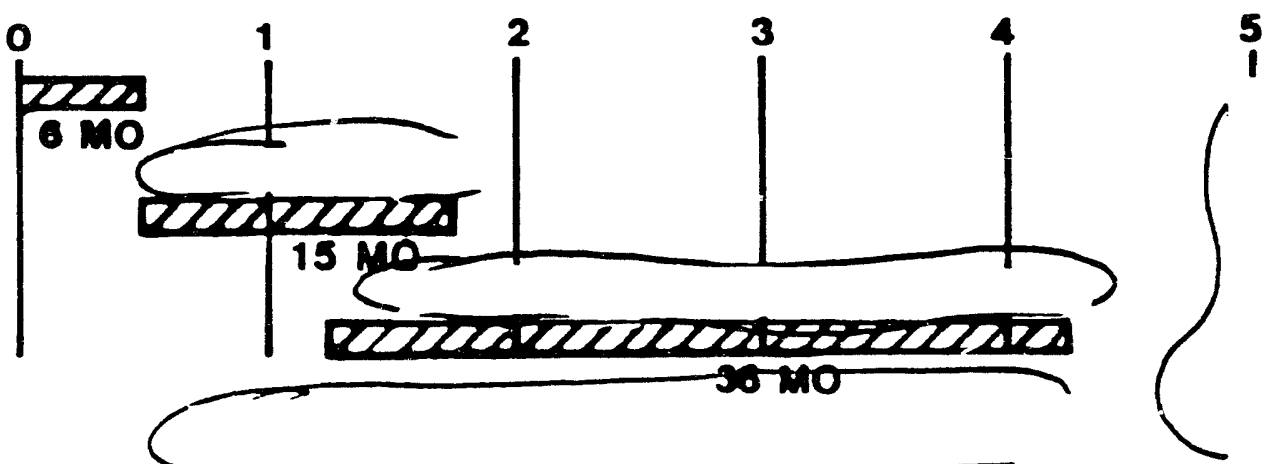

DESIGN

CONSTRUCTION

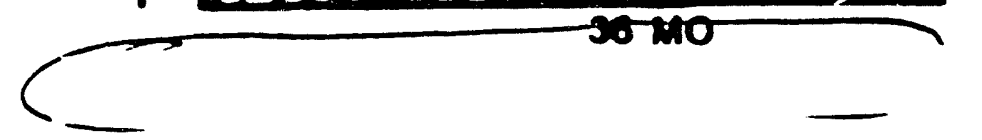





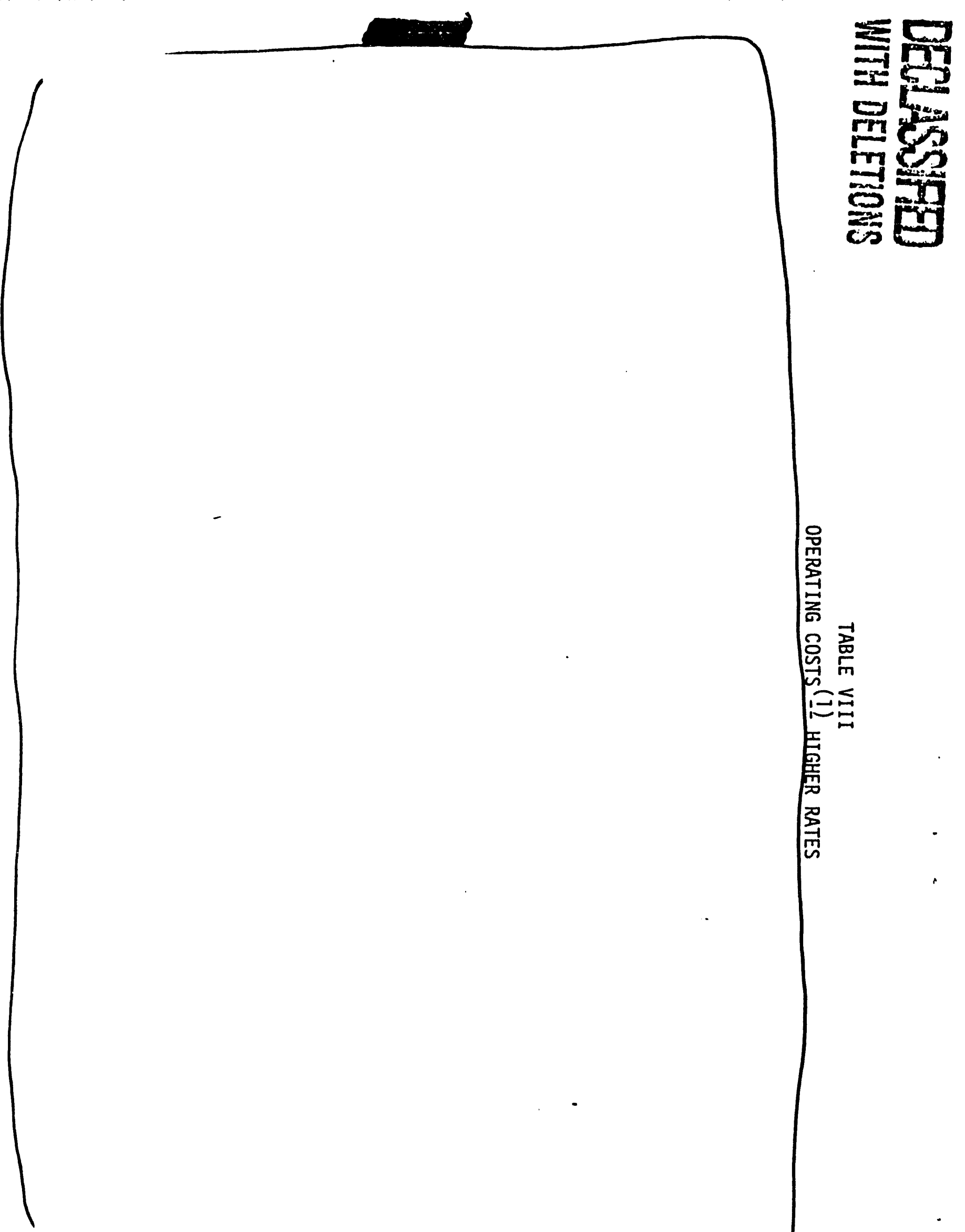

量

ชิ

管

至心

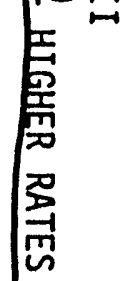

T90 9892-Hidy

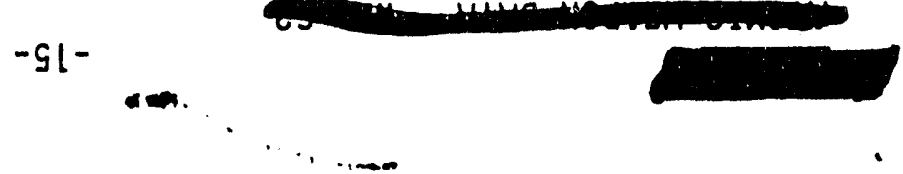



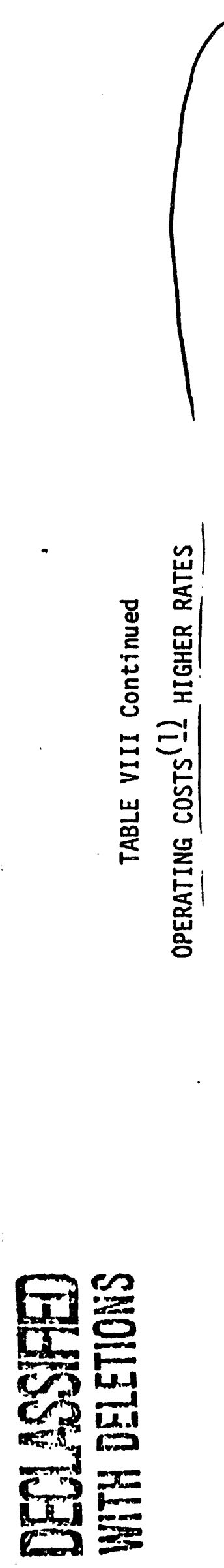
NOTES: (1) PRF is nitrate purification and scrap recovery to pure plutonium nitrate; $B L$ is nitrate to metal (add $15 \%$ to $B L$ costs to go to ingot); $F A B$ includes final inspection and primary assembly. 


\section{FLOWSHEETS}

Flowsheets are shown in the Appendix $C$ for case 4,. $\checkmark$ One of the rates used was 1 - The flowsheets are further explained in Appendix $C$. The flowsheets in the appendix are as follows:

Figure I: Overall Z Plant Flowsheet, -

Figure II: Americium Purification and Scrap Processing: [

Figure III: Waste Treatment for Plowshare, $L$

Figure IV: Plutonium Nitrate to Metal for Plowshare [

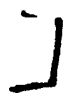

Figure V:

$$
\text { Fabrication Flowsheet } \square
$$

The existing FRF can handle up to

a hign capacity, rich teea (plutonium nitrate and dissolved metal) factilty is added, the existing PRF handling all other plutonium scrap. The Waste Treatment Facility would require replacement of americium hoods and equipment to handle the larger americium outpit.<smiles>C1CC[AsH2+]C1</smiles>

Figure VI: $\quad$ Overall 2 Plant Flowsheet, $\Gamma$

Figure VII: $\quad$ New Rich Feed Reclamation Facility Flowsheet [<smiles>C1=CCCC1</smiles>

Figure VIII: $\quad$ Plutonium Reclamation Facility Scrap Processing Flowsheet

Figure IX: Waste Treatment [

Figure $X$ :

Figure XI:<smiles>CCC</smiles><smiles>CCCCC</smiles>

Flowsheets for cases 1 and 2 can be handled in existing reclamation and plutonium nitrate to metal equipment; fabrication requires renovation of almost all the hoods. The fabrication flowsheets are shown for $L$ 
They are shown in the appendix as follows:

Figure XII: $\quad$ Fabrication Flowsheet Case 1 ,

Figure XIII: $\quad$ Fabrication Flowsheet Case 2,

Flowsheets for other capacities can use multiples of these. Flowsheets for the new bujlding are multiples of existing flowsheets for Cases 1 and 2 and multiples of the [ $\lambda$ flowsheet for Cases 3 and 4 .

RADIATION

Design of new equipment will be such that the exposure at the working face of a hood is $1 \mathrm{rem} / \mathrm{man}$ year. Absolute exposure for personne: will be less than $5 \mathrm{rem} / \mathrm{man}$ year and less than $30 \mathrm{rem} / \mathrm{man}$ year for hand exposure. The average isotopic value of

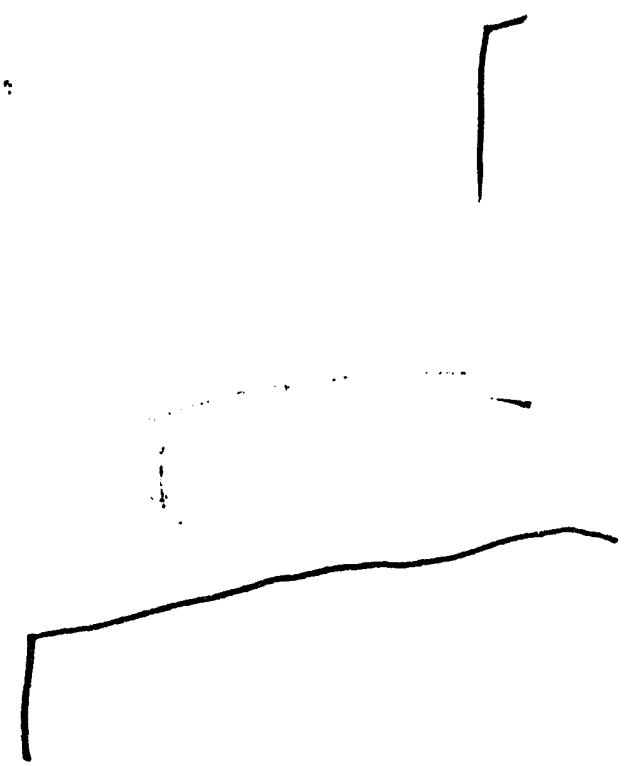
Tplutonium is as follows:
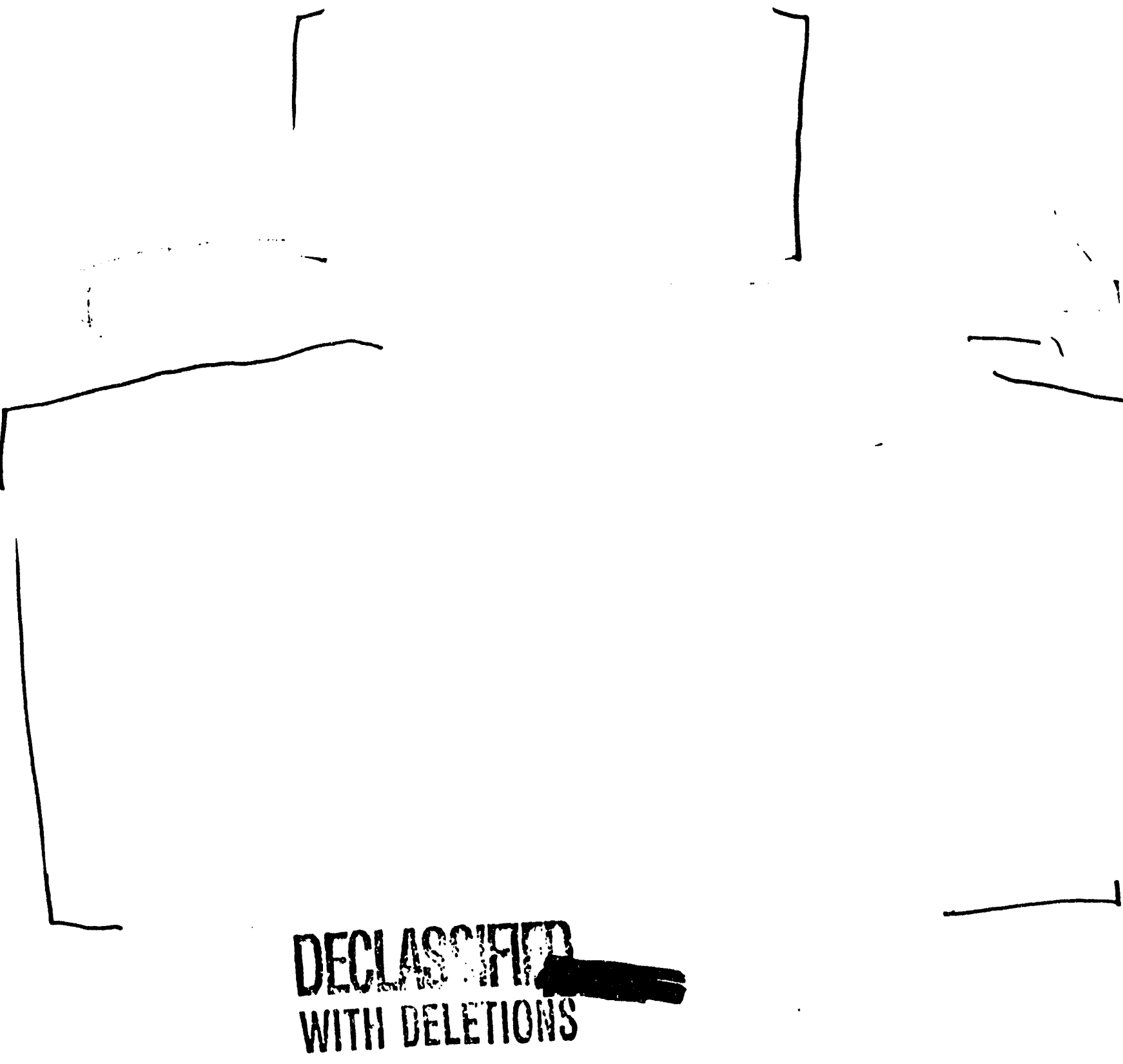


\section{DENISSIFED}

ATP

NOTES: (1) $0.1 "$ represents attenuation for 0.1 inch of stainless steel.

(2) $0.25^{\prime \prime} \mathrm{Pb}$ represents attenuation for 0.25 inch of lead.

(3) Relative neutron exposures given here do not consider the variation in average neutron energies or americlum growth or multiplication. These effects will be small, with minor attenuation -- a few percent. These effects will need to be considered for shielding.

The values on page 19 shows that an operator working with the fluoride powder, for example, can receive 8 times the neutron and 5 times the gamma dose (10 days since americium and $237 \mathrm{U}$ removal)

$\exists$ If the operator receivet $1.5 \mathrm{rem} / \mathrm{man}-y \in$ ar gamma and $2.0 \mathrm{rem}$ per man-year neutron with weapons arade, he could work only a little more than a month in that area with Jand no further shielding. Hence, semiremote operation is recommended, manipulators on one side and a shielded glove panel on the other.

The processes will be highiy instrumented and television cameras would be used wherever practical. Since some amount of manual handling is necessary during glovebox cleanup, maintenance, and assembly, the americium and $237 \mathrm{U}$ should be kept as low as possible. By putting all virgin nitrate through an americium removal step and processing all recycle through the Plutonium Reclamation Facility, a less than 20 -day $241 \mathrm{Am}-237 \mathrm{U}$ buildup can be attained.

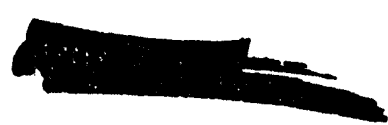



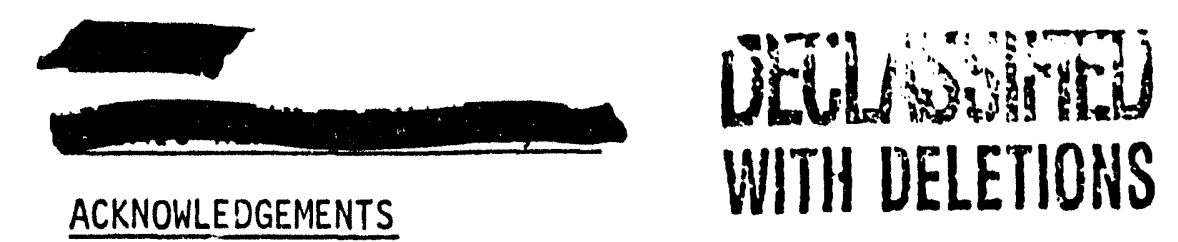

Nith- -505

TEL

\section{ACKNOWLEDGEMENTS}

The author wishes to express appreciation for those who participated in the studies, D. C. Nelson, N. C. Dresser, and W. P. Ingalls of Facilities

Engineering; J. A. Teal and L. I. Brecke of Plutonium Finishing; F. W. Gates, and others of Financial; H. H. Hopkins and A. E. Smith of Research and Engineering; L. M. Knights, R. E. Felt and P. W. Smith of Operations Support Engineering and for the help on the flowsheets by $H$. A. Anderson and the report preparation by C. M. Beggerow and M. R. Ewing.

\section{REFERENCES}

1: -

2. .

3. ARH-2564, L. E. Bruns, "Study (III) Utilization of Z Plant for Plowshare Program" SECRET, July 20, 1972

4.

5. ARH-2544, L. M. Knights, "Atomic Energy Commission Plowshare Task Group Meeting," SECRET, June 19, 1972.

6. TT-13, V. C. Vespe, Albuquerque Operations Office, "Plowshare Program Meeting," SECRET, August 2, 1972.

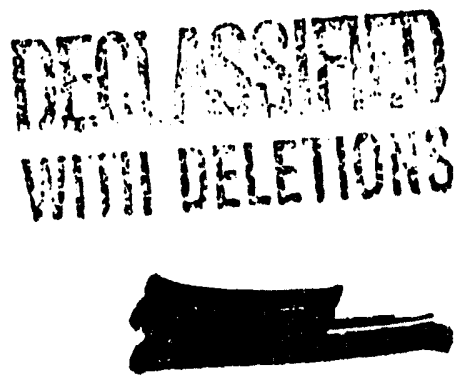




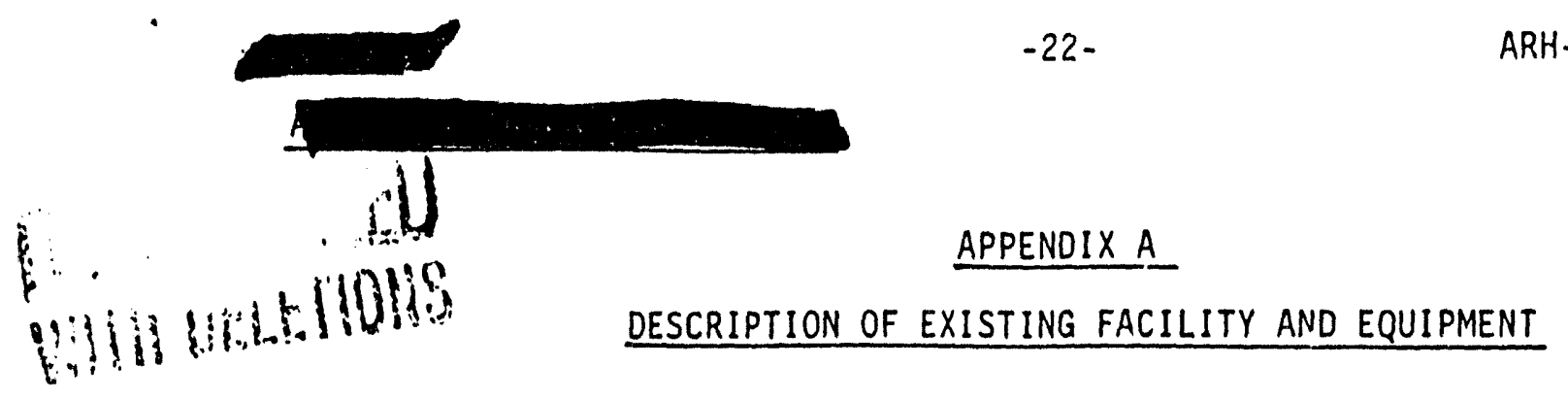

The plant currently in operation has the facilities for conversion of plutonium nitrate to the metal and the recovery of plutonium from scraps and metallurgical residues. Fabrication facilities are present but are in stand-by condition. The plant is known as ? Plant and is shown on the sketch titled " $Z$ Plant Floor Plans," page 24.

The 234-5 Building is a 3-story steel frame structure. The plutonium metal reduction and fabrication operating bays are enclosed in $6-12$ inches of reinforced concrete in rooms running through the center. Processing is performed in stainless steel gloved boxes. Maintenance, laboratory, and other supporting facilities are provided within the bullding. An elaborate ventilation system is installed. Vacuum, compressed air, and exhaust fan equipment are housed in the adjoining 291-Z Building.

Other major processing steps are housed in adjoining bulldings. The 232- 2 Building is employed for scrap incineration. The 236-Z Building houses the solvent extraction process for the recovery of plutonium from scrap behind. 2 feet of concrete. The 242-Z Building houses the waste treatment and americium recovery processes. Not shown is a new plutonium storage facility which meets all AEC criteria including that for tornado and earthquake resistance. Analysis of the $234-5,236-Z, 242-Z$, and $232-z$ Buildings for tornado and earthquake resistance has not yet been made, but experience has shown the ir ability to withstand winds up to $80 \mathrm{mph}$.

There are areas within the 234-5 Building where new equipment can be installed without disturbing any current operations. For example, a new shielded, semiremote button line could be installed in empty room 221 , along with a new compact remote rich feed reclamation facility (see flowsheet, figure VII). The fabrication area is available for hood renovation.

Throughout the entire $Z$ Plant complex, all equipment has been constructed of geometrically favorable design wherever possible to enhance nuclear safety.

The Z Plant was recently analyzed for fire safety by the Factory Mutual Research Corporation of Norwood, Massachusetts (H-S-13 [secret], January 29, 1971, "Fire Protection Review -- Atlantic Richfield Hanford Company 200-West Area, Building 234-52 Area, Richland, Washington"). The conclusions drawn gave a high fire safety rating to the $Z$ Plant. Their major recommendation was to inirease the sprinkler system coverage, and this is being provided. This facility may then be classed in the "preferred" risk category.

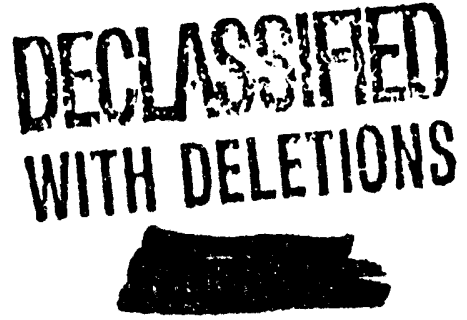




\section{DECLASSIFIED -23-}

It can be concluded that the existing $Z$ Plant facility and equipment therein offer a powerful system to the Plowshare Program. At today's dollars, this complex, with its usable equipment, is estimated at $\$ 65,000,000$. All systems throughout are well known and well understood. Some of the existing equipment is relatively new; and analytical laboratories, development laboratories, maintenance shops, nondestructive counting areas are unique and well equipped. A completely integrated facility is then available for processing plutonium from the nitrate to final device form, including associated scrap recovery work. 


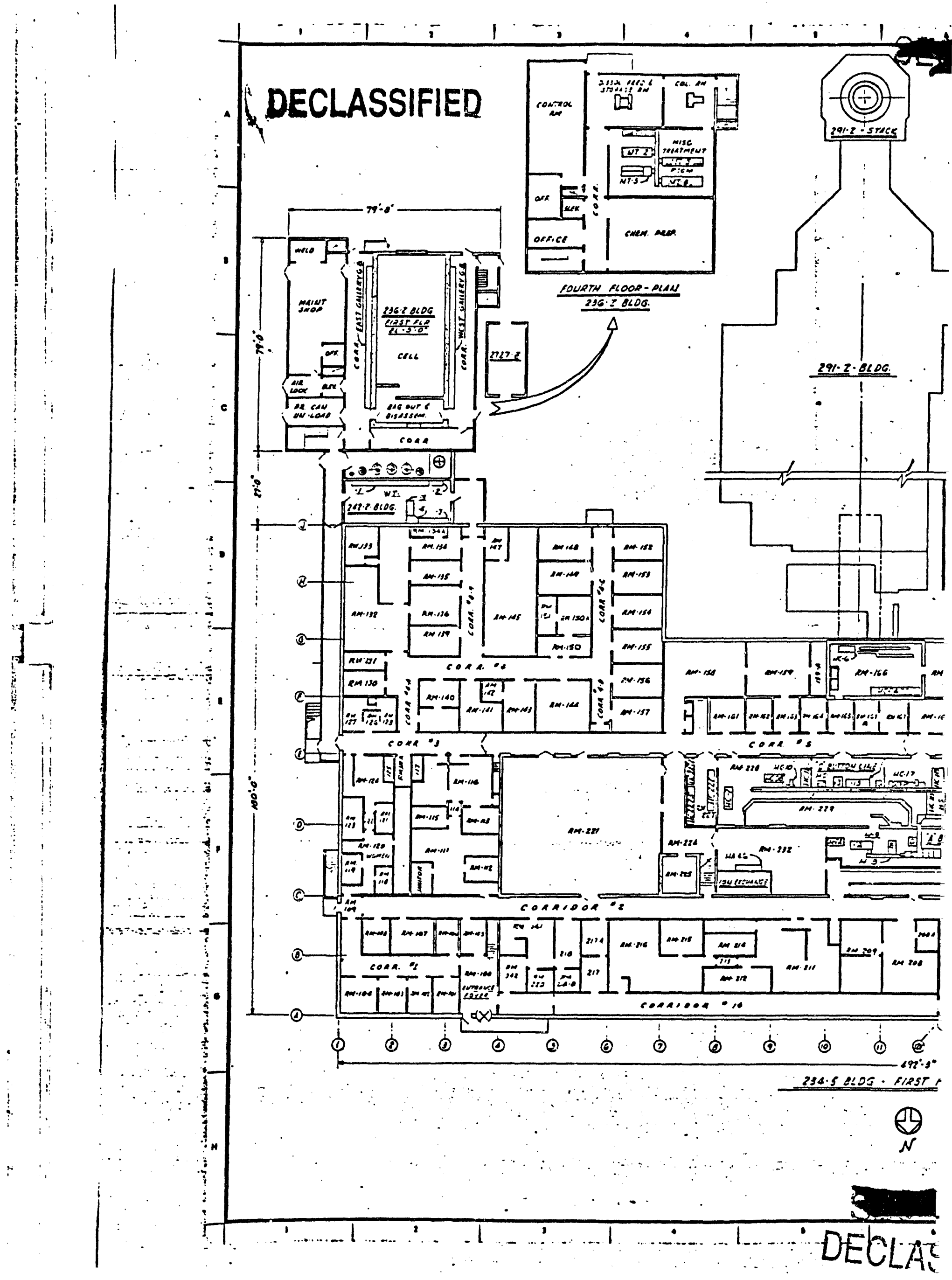




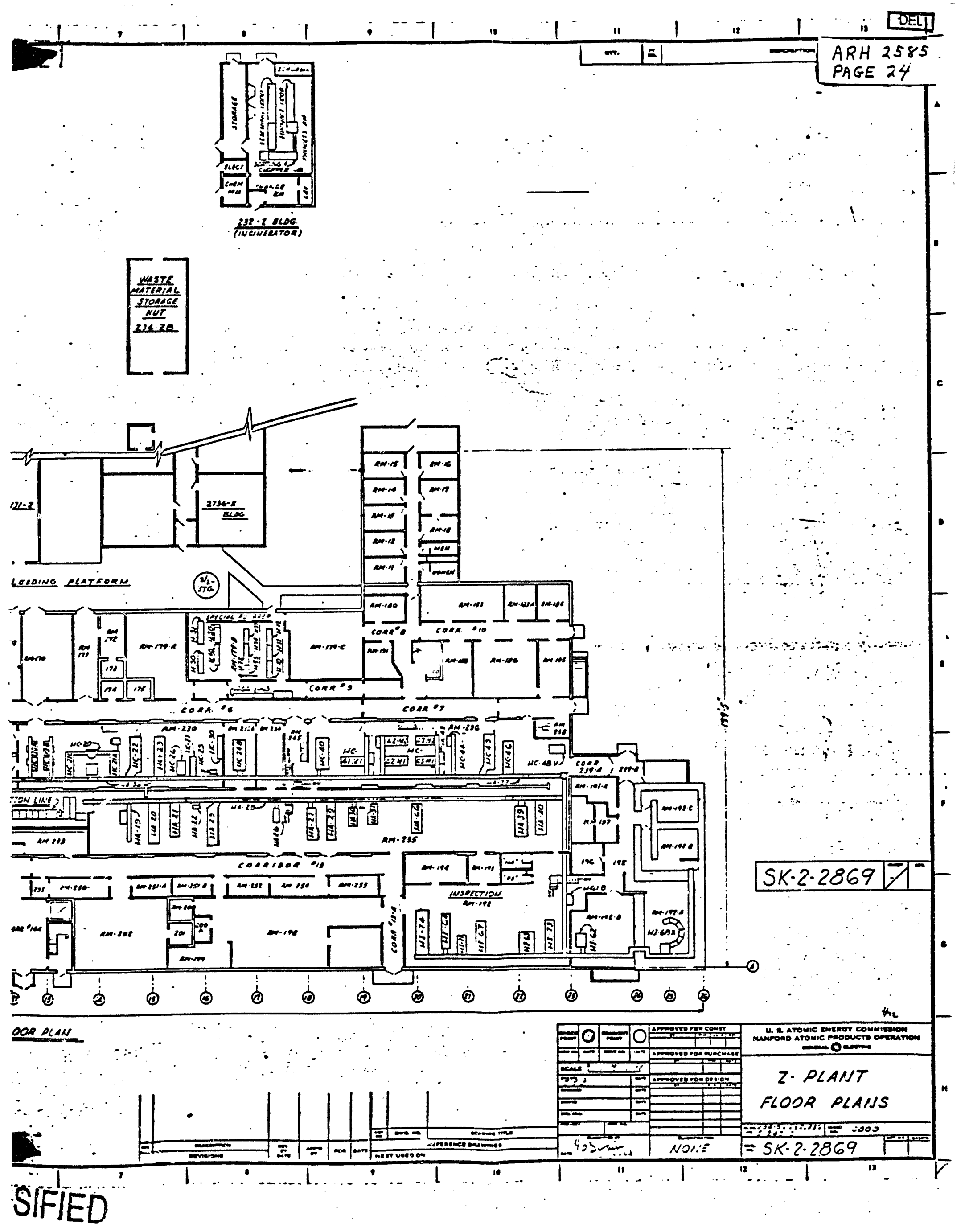




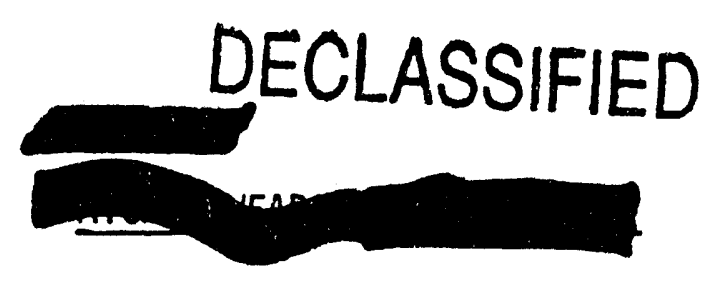

\section{APPENDIX B}

\section{OPERATING EXPERIENCE}

The Atlantic Richfield Hanford Company has professional and operating personnel with up to 25 years experience in plutonium processing, including extractive metallurgy, scrap recovery, metal fabrication, and nondestructive testing. ARHCO is currentiy engaged in processing feeds for both defense and civilian application and the recovery of scrap. ARHCO serves as a central scrap management operation for the Atomic Energy Commission, and has been designated as the national plutonium site.

At the Hanford site, the expertise of many scientific disciplines is available. For example, Pacific Northwest Laboratory (Battelle Memorial Institute) personnel have dealt with all phases of plutonium fabrication. Wastes, which must be disposed of, will be treated by ARHCO waste management experts and, thus, will not have to be shipped off-site for treatment. 
The flowsheets on the ensuing pages are brief plutonium path flowsheets. Since volume can be limiting in all systems, volume and plutonium paths are shown. In some cases, key chemicals are also shown.

Figure I through Figure XI -5

The first series of flowsheets Fig. I through Fig. V, selected have

can use multiples

JAll simitar flowsheets

Jthe maximum expected.

Assumptions made for these flowsheets are as follows:

1. All virgin feed enters the system at about $200 \mathrm{~g} / 1$ plutonium nitrate solution.

2. All plutonium nitrate goes through the PRF to remove americium and uranium-237.

3. All recycle from the button line and fabrication immediately goes back through PRF. The object of this and item 2 are to keep the hand exposure from Am-241, and U-237 gamma at a minimum. The flowsheets are aimed at providing less than 20-day old plutonium since Am and $U$ separation, thus allowing some selective manual handling, such as during the intricate task of final assembly.

4. Sufficient nitrate blending capacity is avallable $\Gamma_{\text {. }}$

Additional blending equipment will be part of the new rich feed reclamation facility, see Fig. VII,

5. For all processing off

capacity button line is assumed using the proven fluoride process. Development work will stress the pyrochemical process patented by ARHCO's Dr. R. E. Felt (ARH-1198, R. E. Felt, "A Pyrochemical Process For The Reduction of $\mathrm{PuO}_{2}$ To Metal", July 1969) for this process could reduce both capital and operating costs and radiation exposure rates.

6. The gallium addition to attain the delta phase will be added in the ingotting step.

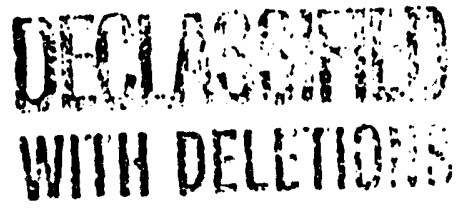


Flowsheets I and VI are the overall flowsheets respectively, showing the path of plutonium from original nitrate to the final assembly, with plutonium wastes safely stored in underground tanks in solid form. These flowsheets show the major recycle streams that go back through reclamation to keep the gamma exposure from U-237 10-50\% below maximum and Am exposure tolerable for necessary hood glove manual handling (maintenance, scrap cleanup, loadout, loadin, sorting, part measurements, final assembly). The major recycle streams are the supernates from the oxalate precipitation process, plutonium oxalate, oxide and fluoride sweeps (hood cleanouts), slag and crucible, reject metal, ingotting and casting crucibles, ingotting skulls, sprues, briquetted turnings, samples, miscellaneous (rags, containers, gloves, plastic bags, fabrication oil, etc) and reject parts.

Flowsheet II is the flowsheet for the existing PRF (Plutonium Reclamation Facility). The PRF has successfully processed $200 \mathrm{~kg}$ Pu/month on a 15 shift per week ( $X Y Z$ shift) as scrap into the solvent extraction system and $30-40 \mathrm{~kg}$ Pu/day via the solvent extraction recycle system. Since high concentrations of relatively pure solutions can blend into the recycle system, feeds like $200 \mathrm{~g}$ Pu/l plutonium nitrate can be added in the recycle stream without seriously affecting the scrap feed capacity. In Flowsheet II the virgin Pu nitrate is added to the recycle stream. More product concentrator capacity and improved solvent extraction instrumentation will be required and these are incorporated in capital costs. The estimated capacity for the existing PRF if $300 \mathrm{~kg} \mathrm{Pu} /$ month on a 21 shift per week basis (ABCD shift) from scraps and $400 \mathrm{~kg} \mathrm{Pu} /$ month ( $A B C D$ shift) as recycle. The recycle feed must be such that the nitric acid scrub section in the extraction column will remove the bulk

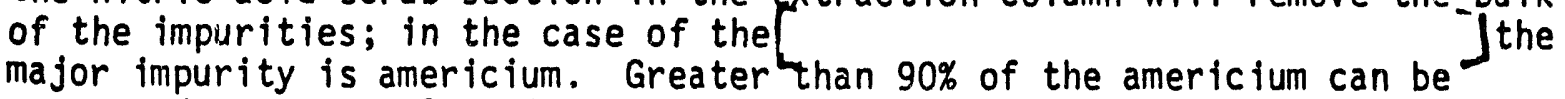
separated from the plutonium by this technique.

Figure III, $\Gamma$

Joes not seriously tax the waste cleanup columns. However, the americium puritication is taxed and at this point the facility requires replacement with a higher capacity system. The losses of $\mathrm{Pu}$ and $\mathrm{Am}$ to ITS (in-tank-solidification) may be overstated since recovery from the newly installed centrifuges was not considered. Also, recent improvements in the Am purification process indicate the losses shown in Fig. III may be overstated.

All liquid wastes will be piped to waste evaporators for concentration and then go to the ITS (in-tank-solidification) tanks for safe storage as a salt cake. Liquid wastes include the high salt, acidic wastes shown as final effluents in Fig. III plus sump wastes which are mostly water (e.g. steam condensates, cooling water, scrubber solutions, lab wastes). Solid wastes like centrifuge residues that no longer have economically recoverable $\mathrm{Pu}$ are dried, placed in steel 55 gallon drums and stored underground. Figure IX, Waste Treatment Flowsheet equipment is required to meet the capacities shown. In this case, new Am purification

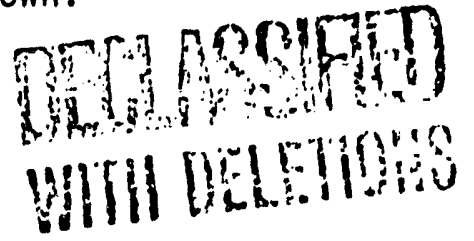


Fig. IV and $X$ are the button line (nitrate to metal) flowsheets]

1 The

difference will be in the number of shifts and the number of people per shift. The estimated capacity for a 1-shift/day operation is $8 \mathrm{~kg} \mathrm{Pu/day,} \mathrm{2-shift} \mathrm{is}$ $19 \mathrm{~kg} \mathrm{Pu} /$ day and 3 -shift is $32 \mathrm{~kg} \mathrm{Pu} /$ day, all average rates. The new button line will consist of receiving, blending and storage tankage, oxalate precipitation tankage; drum filters and supernate treatment facilities; calciner, fluorinator and reduction furnaces; button breakout and slag and crucible handling facilities.

Fig. $V$ and $X I$ show the main metal to assembly steps for delta metal fabrication. The gallium will be added at the ingotting step. Silicon nitride (SiN) crucibles will be used in the ingotting step; carbon and SiN crucibles will be used in casting. After sprue removal, the plutonium balls may require a contour adjustment such as coining or electropolishing. The primary part will be formed to its required shape by a power-roll system. $f$

1 Turnings will be briquetted and sent back to recovery along with reject metal, fabrication oil, and other miscellaneous scrap. The assembly costing considered only that for primary component.

Fig. VII and VIII are the new Rich Feed Reclamation Facility and the existing PRF flowsheets, respectively. The new plant would be a high capacity compact facility having nitrate blending capabilities, electrolytic dissolvers, necessary solvent extraction tankage and compact centrifugal contactors, for an extraction and stripping system. The facility would be installed in the existing 221 area of the 234-5 Building along with the new button line. It would be a completely shielded remotely operated facility.

The new reclamation plant would handle only rich and relatively pure feed. The plutonium nitrate being recycled would be added at the fourth stage giving 4 stages of nitric acid scrub to remove the americium (98\% removal). Electrolytically dissolved metal would be added at the 7 th stage along with necessary salts to insure complete gallium and other impurity removal. Iron nitrate is added as one of the salts to minimize breakdown of the organic solvent tributyl phosphate.

Centrifugal contactors were planned for use in the new facility to lower the residence time of high exposure plutonfum in contact with the organic, the object being to reduct the radiolysis effect on the organic. The extraction waste from the new facility would go to waste treatment. Any spent solutions (e.g. floor spills) would go to the currently existing facility for recovery. The product handling system would include necessary tankage and a falling-film evaporator capable of concentrating $50 \mathrm{~kg}$ Pu/day from 60 to $200 \mathrm{Pu} / 1 \mathrm{iters}$.

The currently existing PRF would handle all other scrap, such as slag and crucible, incinerator ash, supernates, Pu sweeps, floor spills from both plants and other miscellaneous scraps. Organic cleanup columns are available to handle spent organic from the new facility.

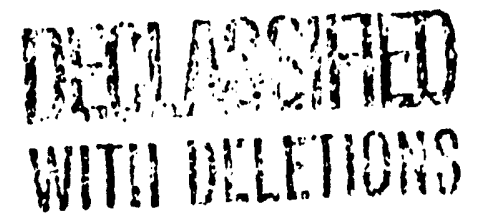


Weapon Grade Flowsheets

The WG (weapons grade) plutonium has been processed many years at $Z$ Plant hence flowsheets for all phases of the planned Plowshare programs with the exception of assembly are covered by existing flowsheets and know-how.

Two flowsheets are shown in Fig. XII and XIII

1 Some shielding is required to assure present day exposure criteria. Beyond the button line existing hoods would require renovation. New assembly hoods are required.

\section{Flowsheets for New Building}

Flowsheets_for the new building will be similar to those shown in Fig. I through $V$ the values in these flowsheets would be multiplied by the units/year desired ilities, including the reclamation and waste treatment facilities will originally be large enough to handle,

For the weafons grade systems the reclamation, waste treatment and button line facilities will be compact units, approximately half the size of the existing units. Plutonium fabrication will be similar to that handled in the past and planned for the Plowshare program within the 234-5 Building. Existing flowsheets will handle all cases for weapons grade.

\section{DECUSSPED WITH DELETIONS}


FIGURE I

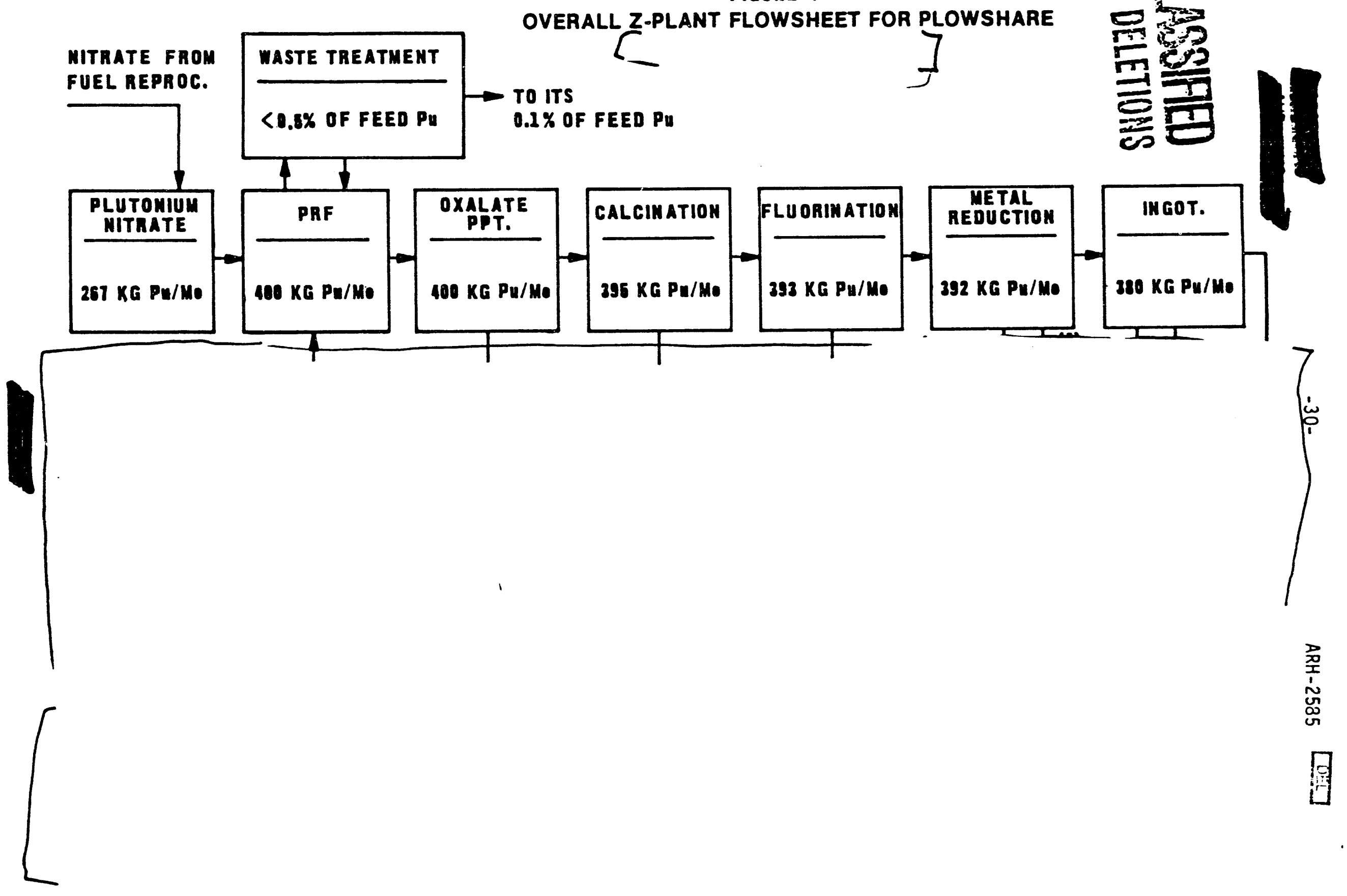


FIGURE II

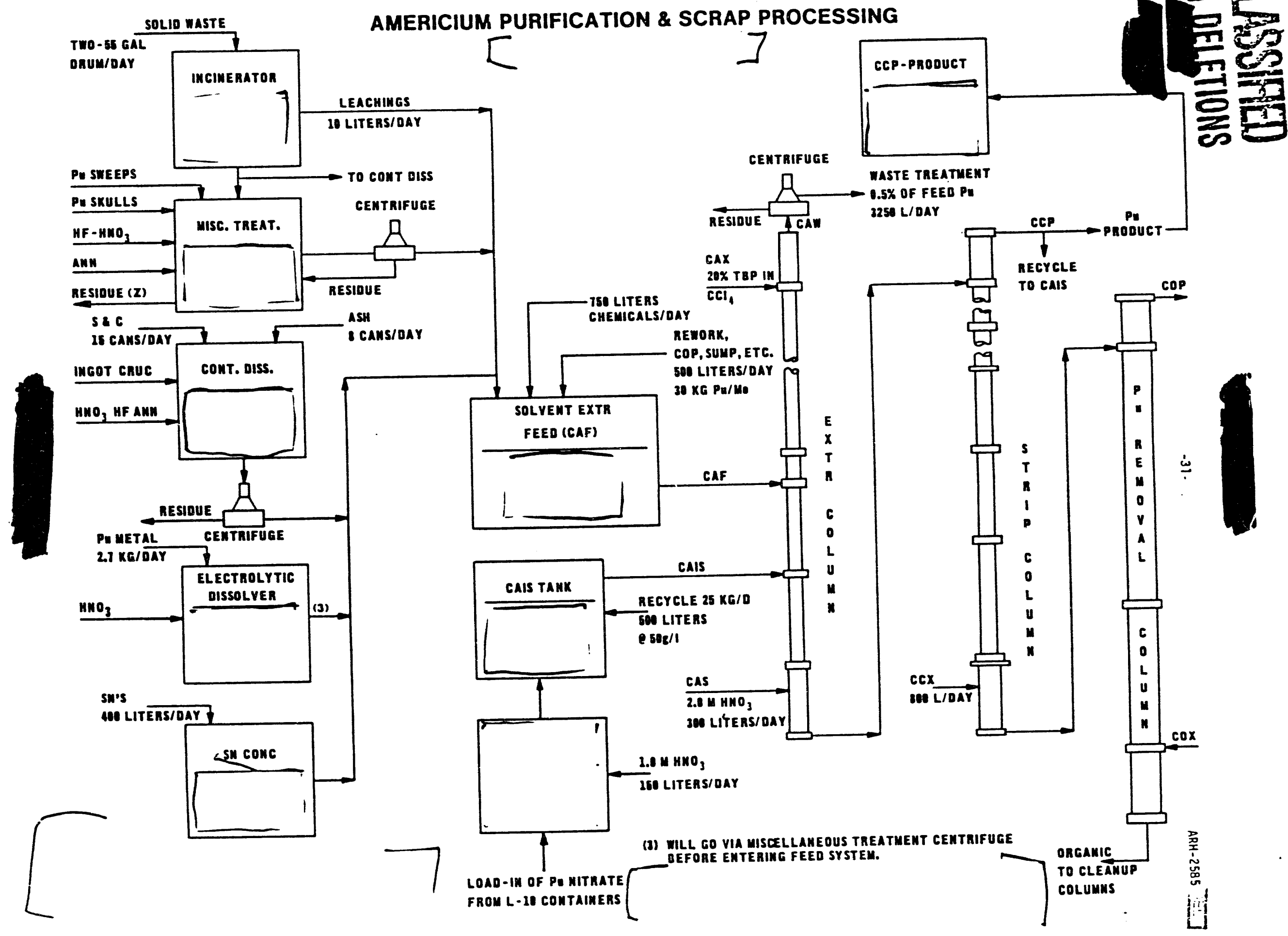




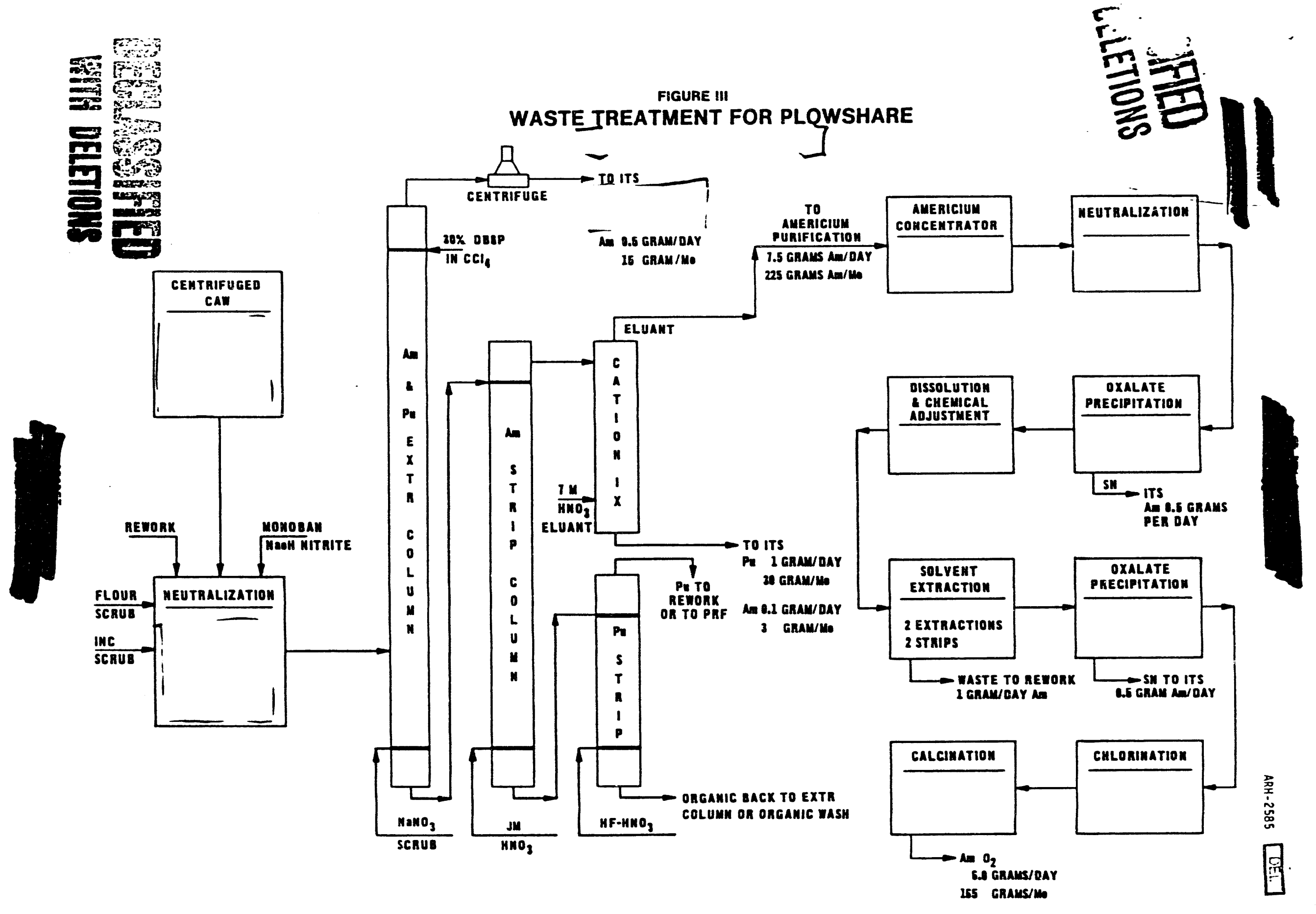




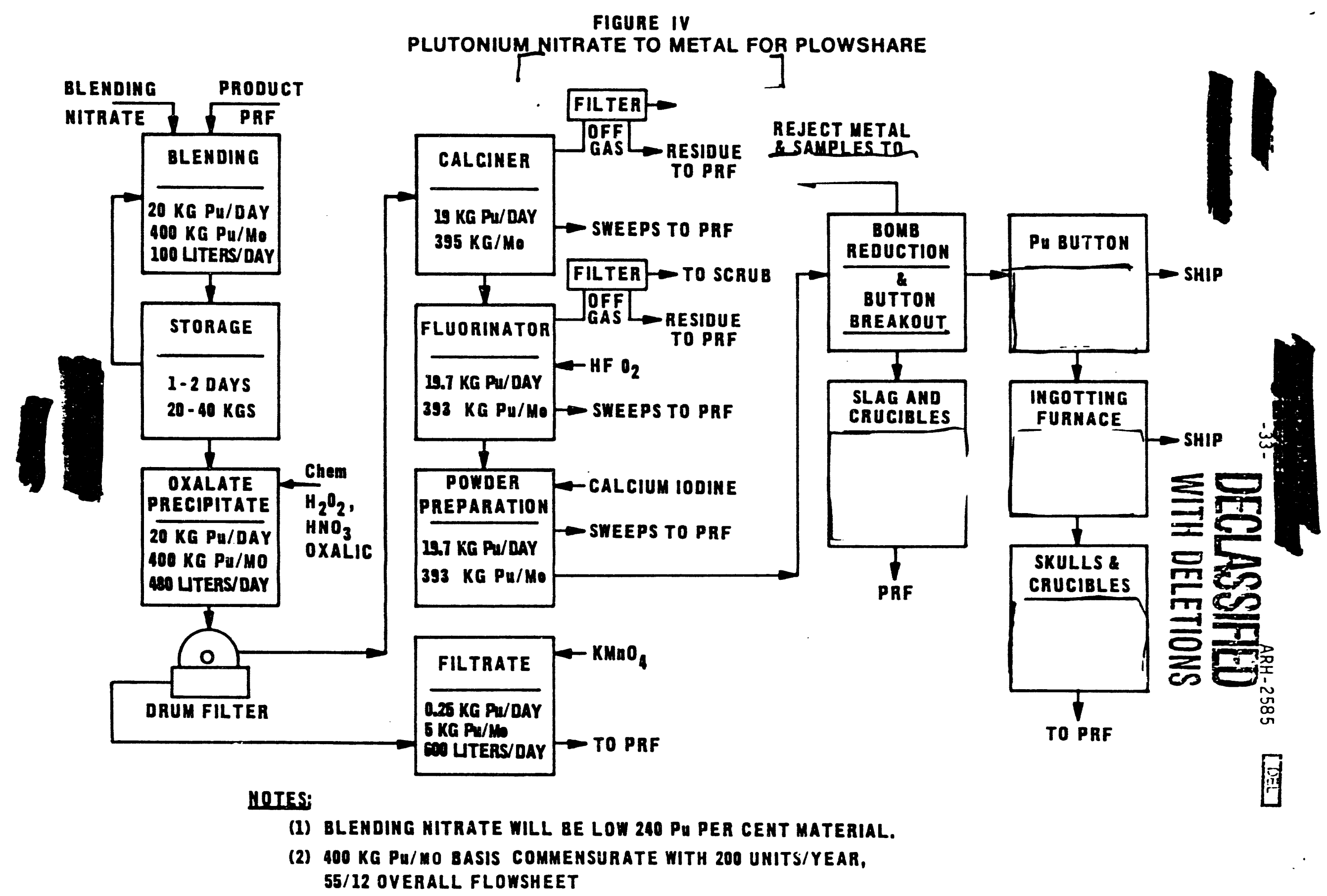




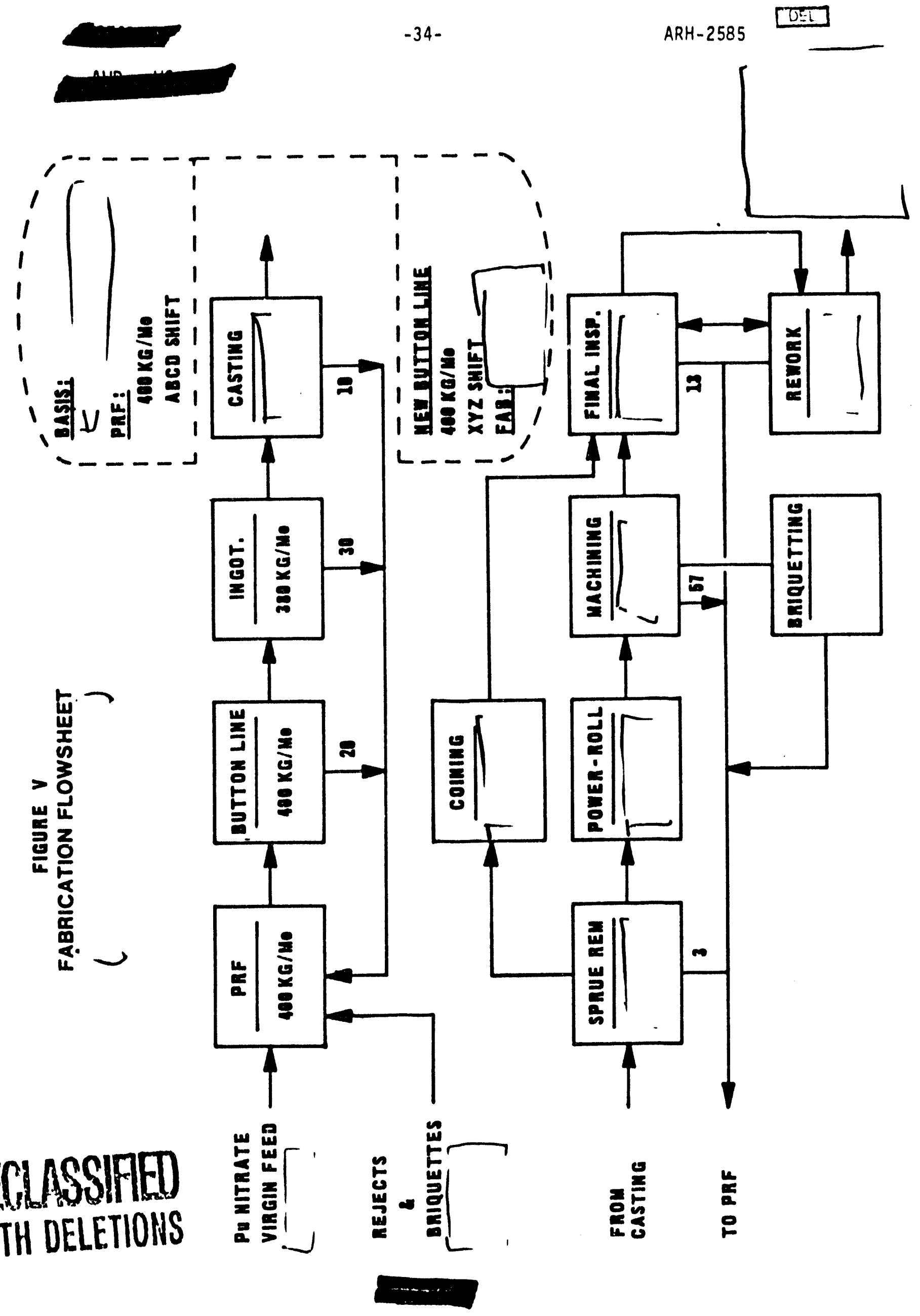


FIGURE VI

FROM EXISTIM G

OVERALL $Z$ - PLANT FLOWSHEET

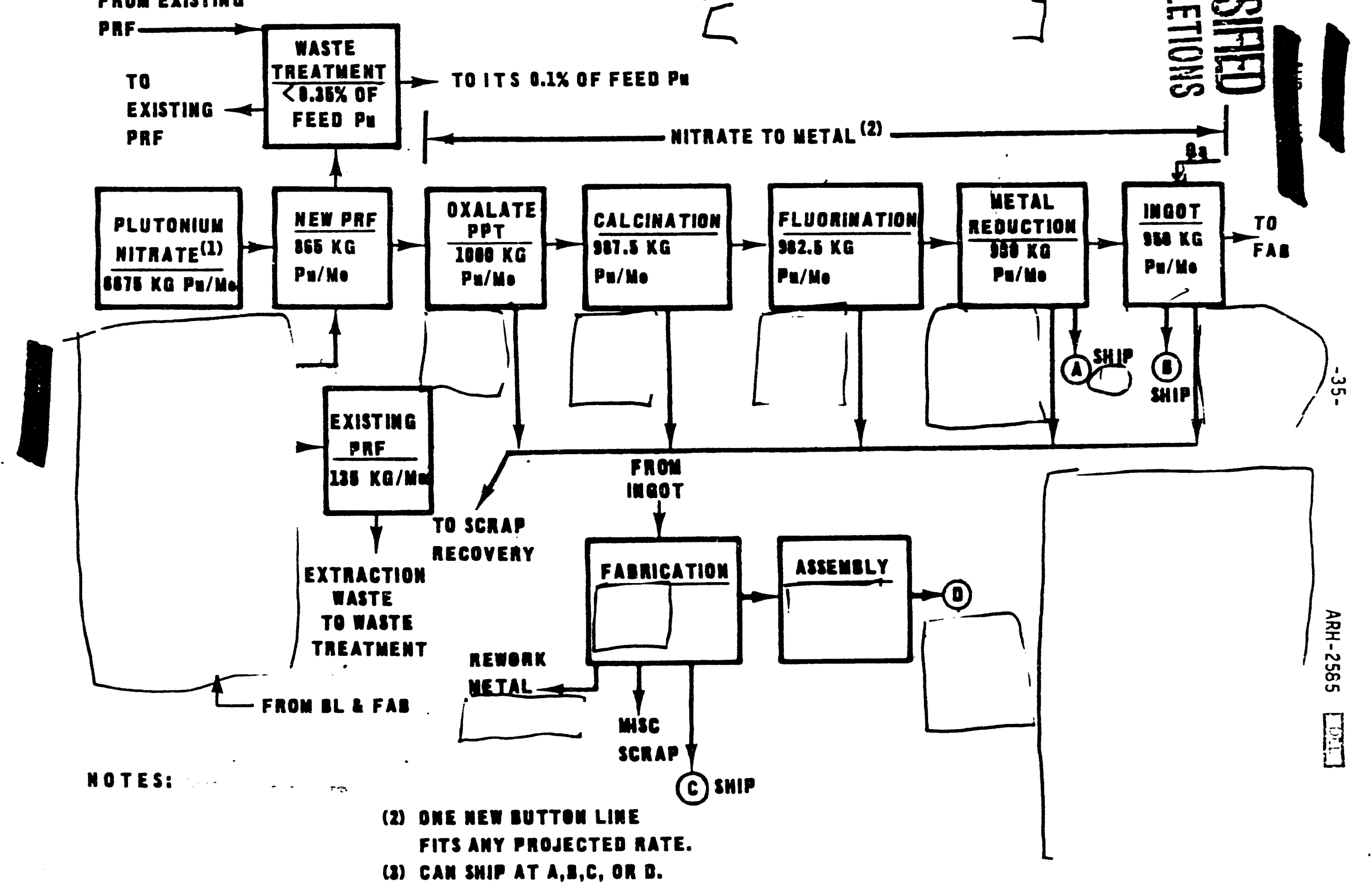


FIGURE VII

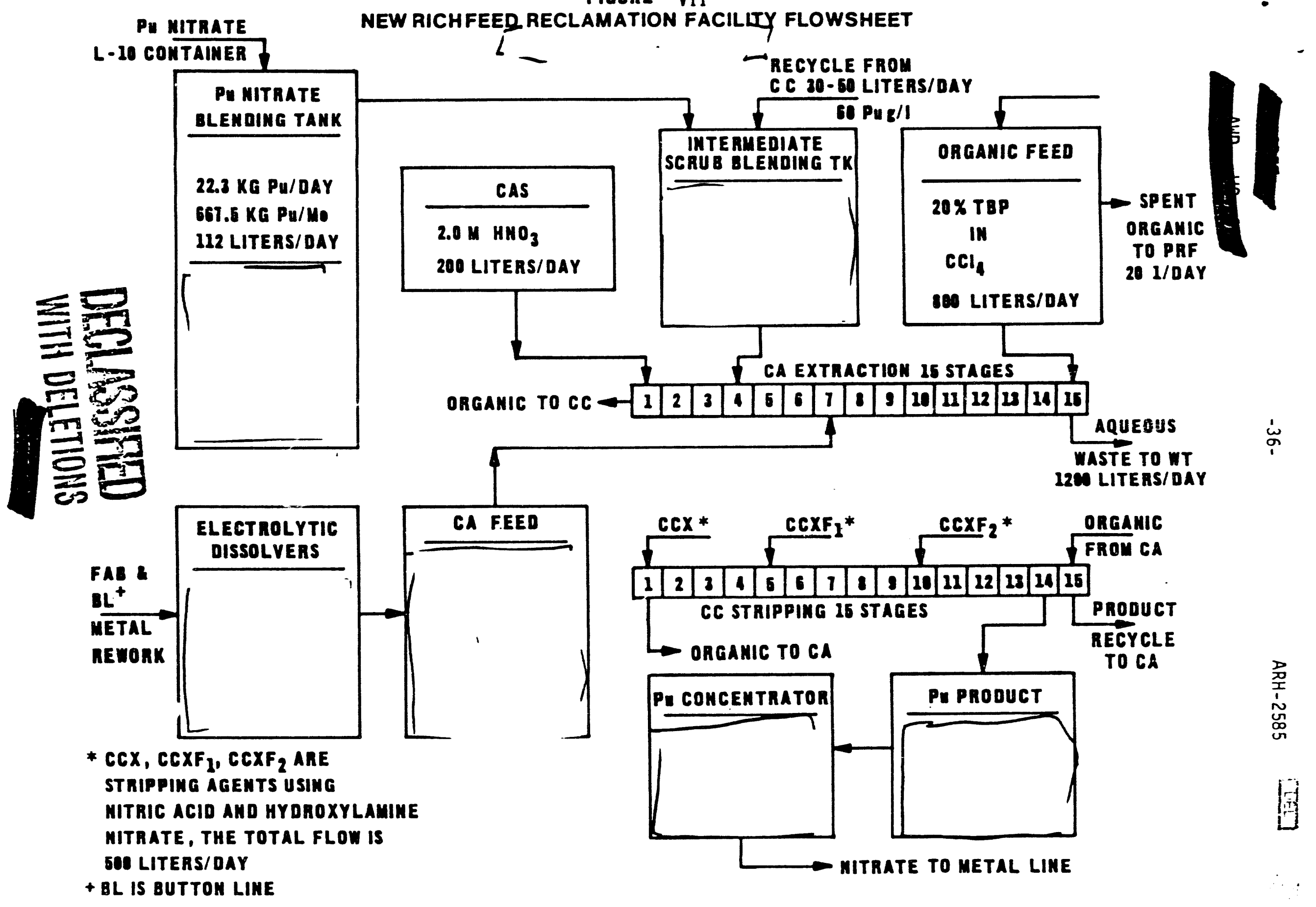


FIGURE VIII

PLUTONIUM RECLAMATION FACILITY

SCRAP PROCESSIMG FLOWSHEET
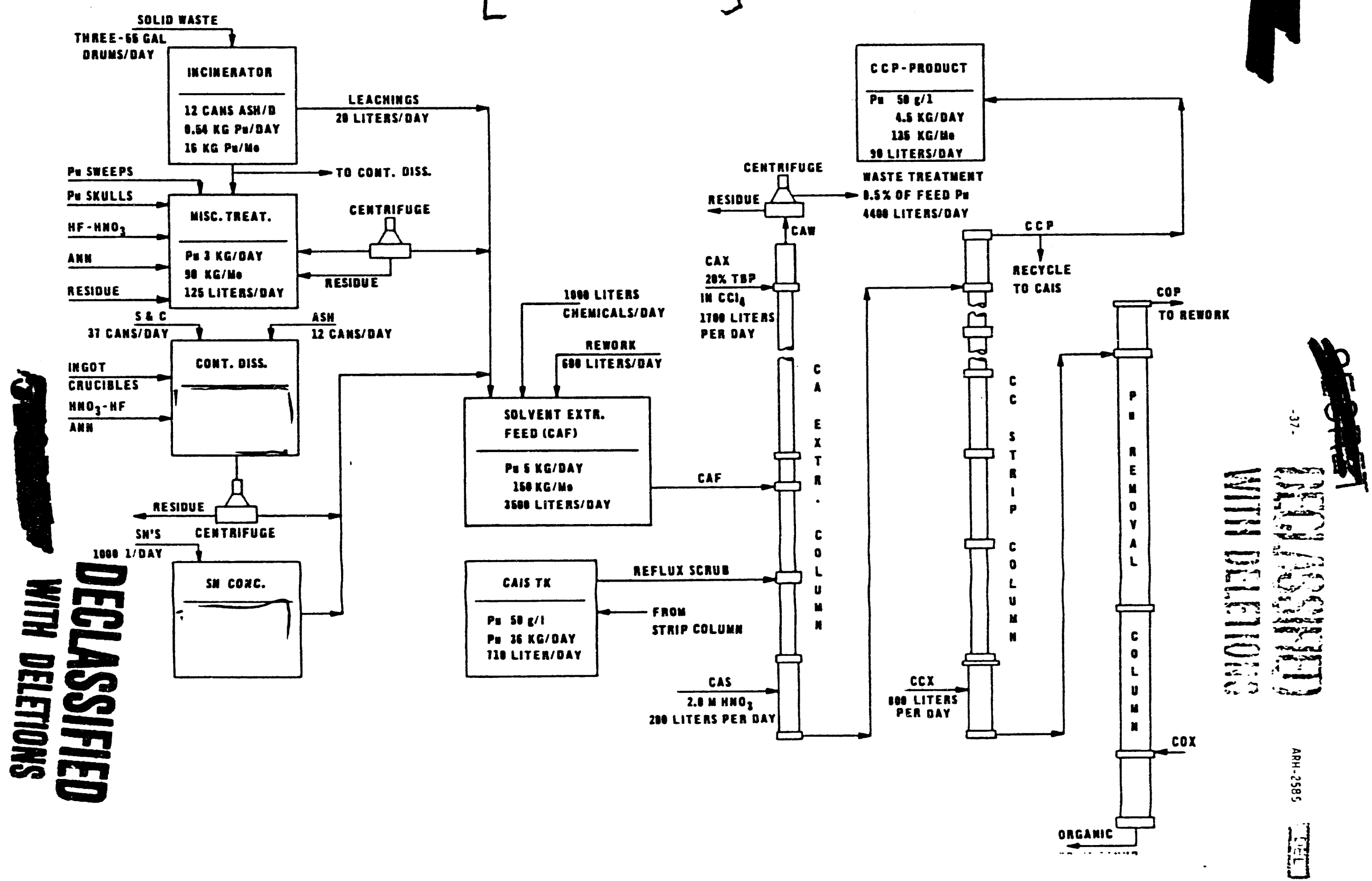


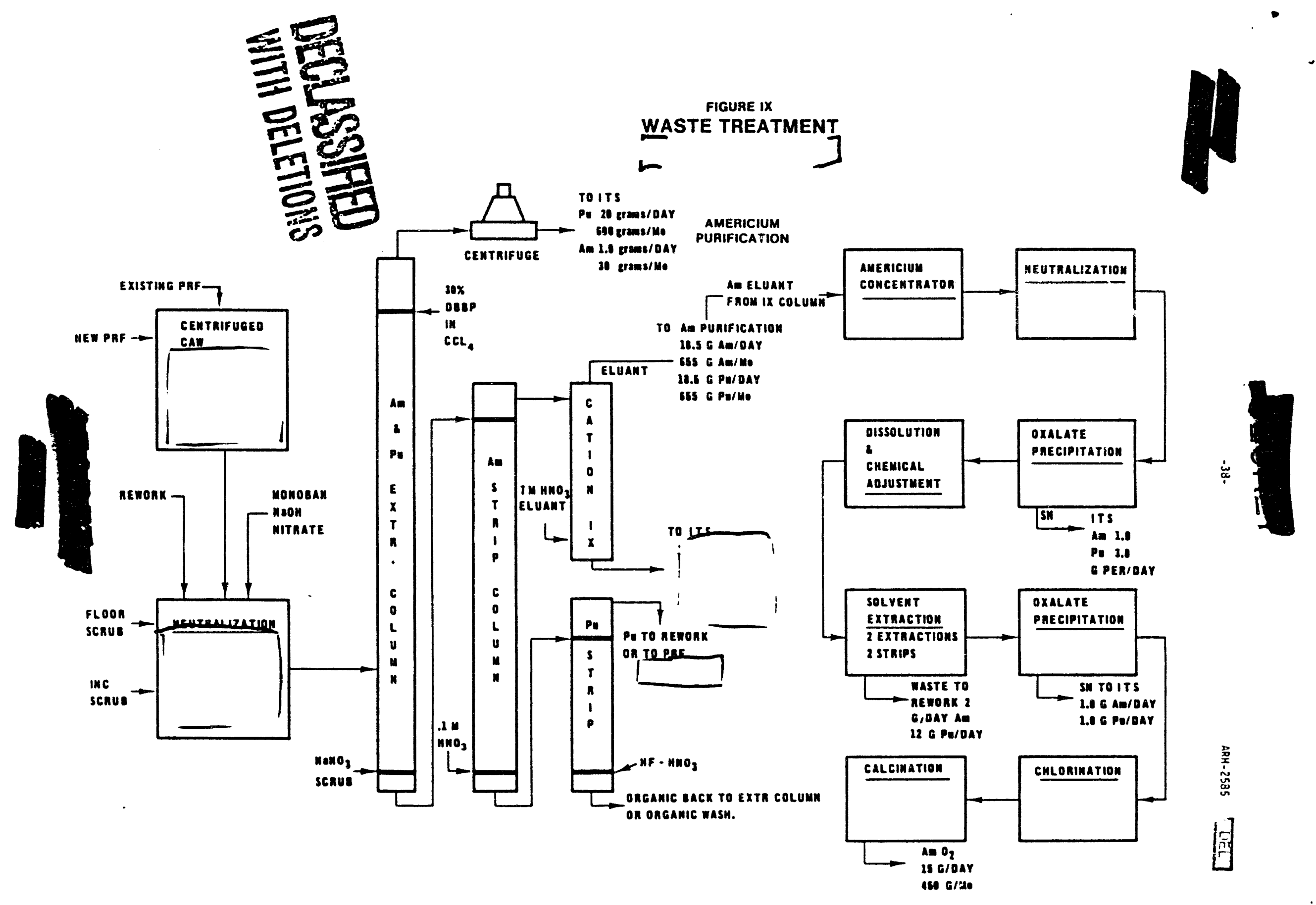


FIGURE $X$

PLUTONIUM NITAATE TO METAL $[$.

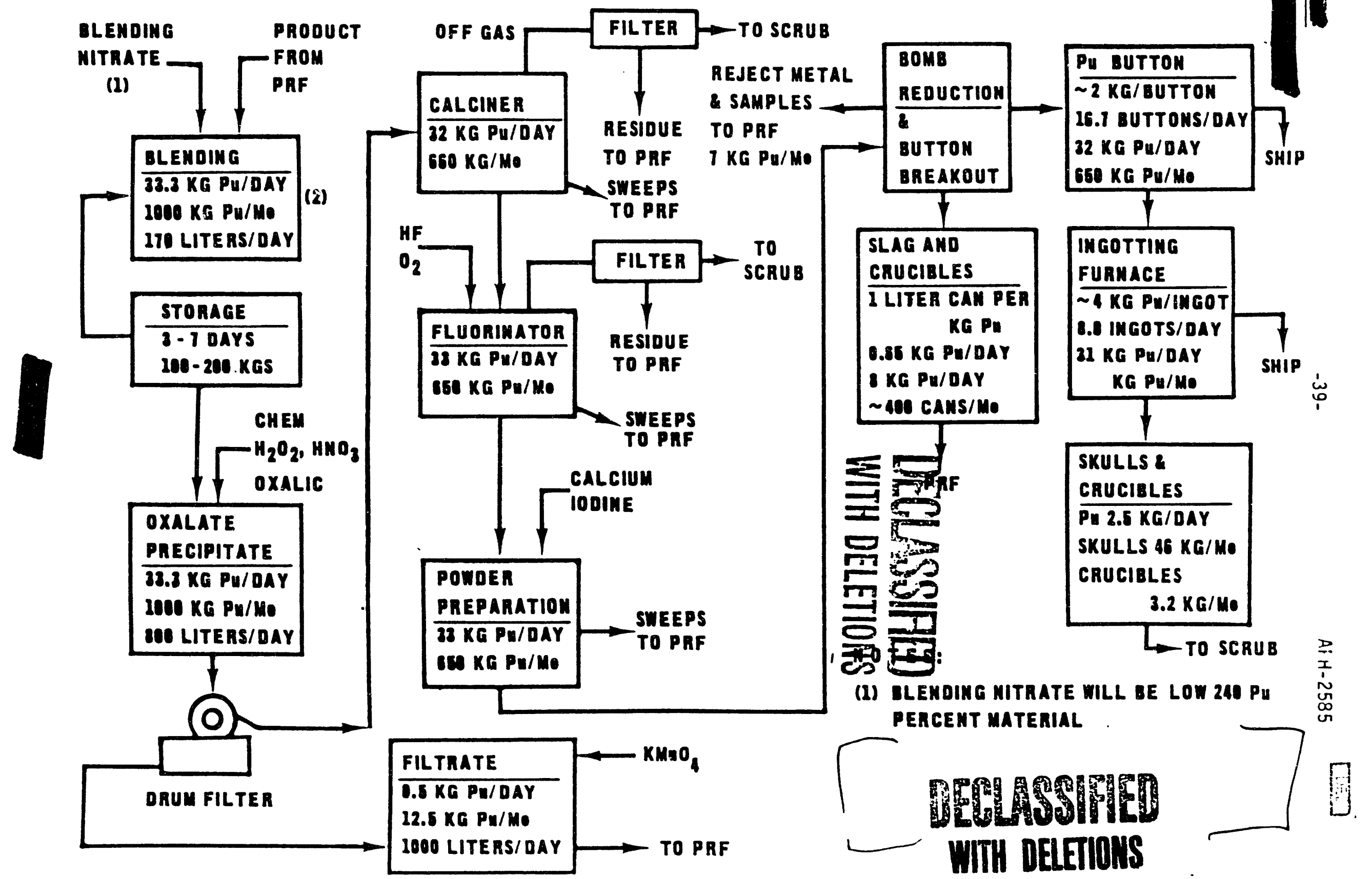


FIGURE XI

FABRICATION FLOWSHEET ;

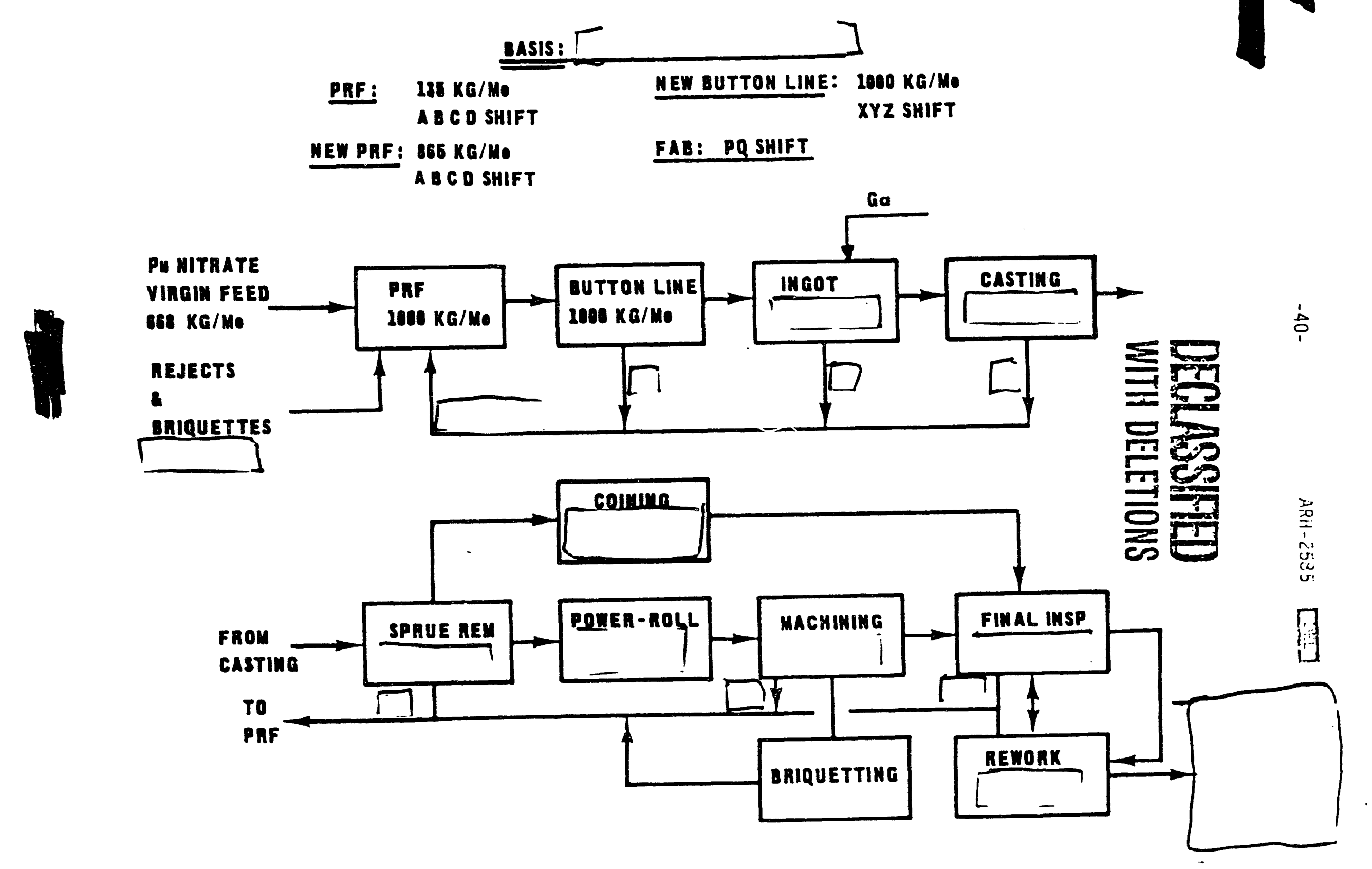


FIGURE XII

FABRICATION FLOWSHEET CASE 1

STORED WG METAL

OXIDE OR MITRATE

50 KG/MO

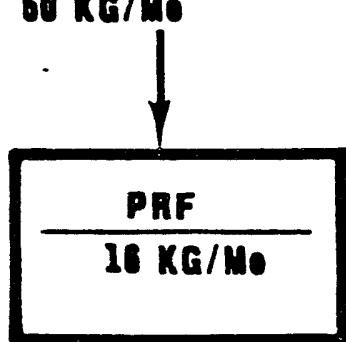

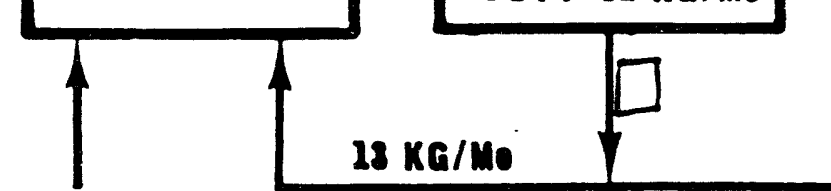

heronk

$-$

$+2$

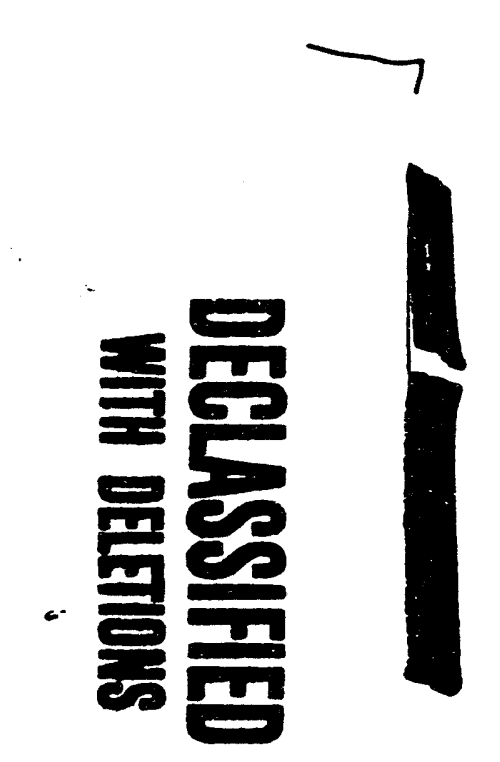

isostatic

pressure

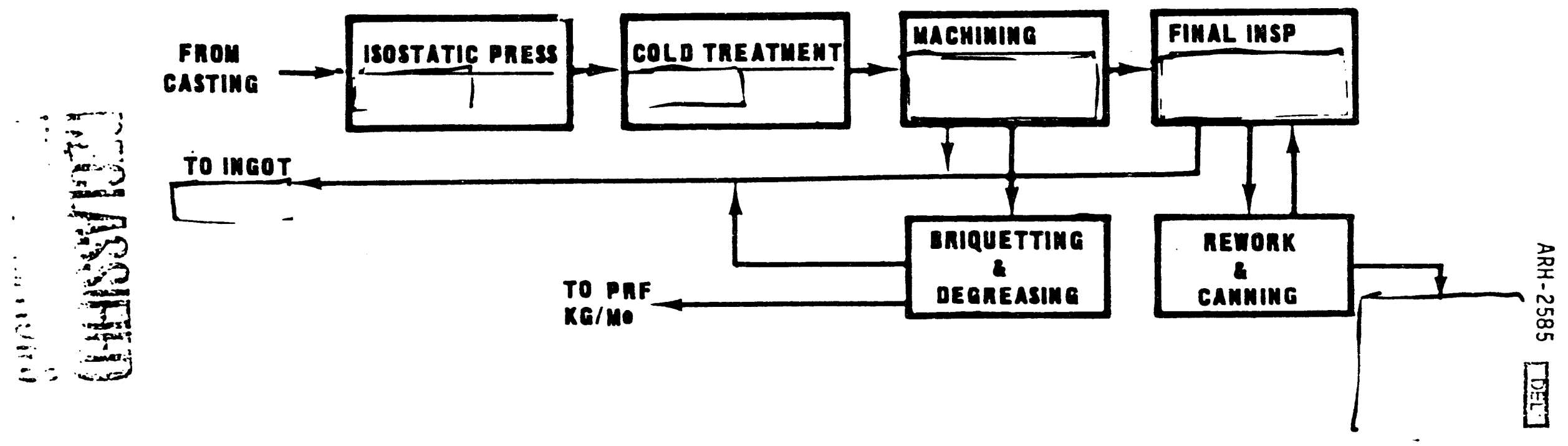




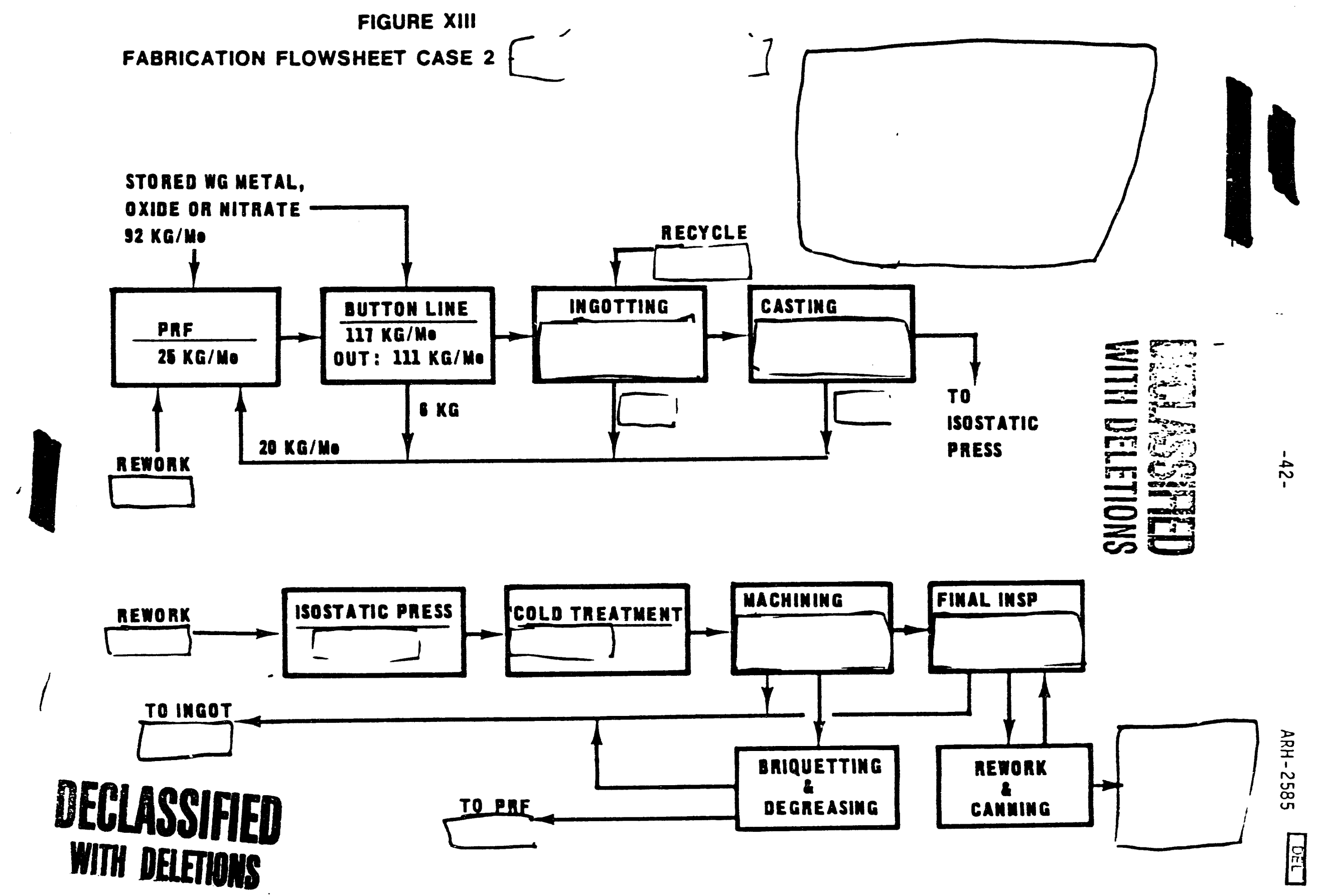



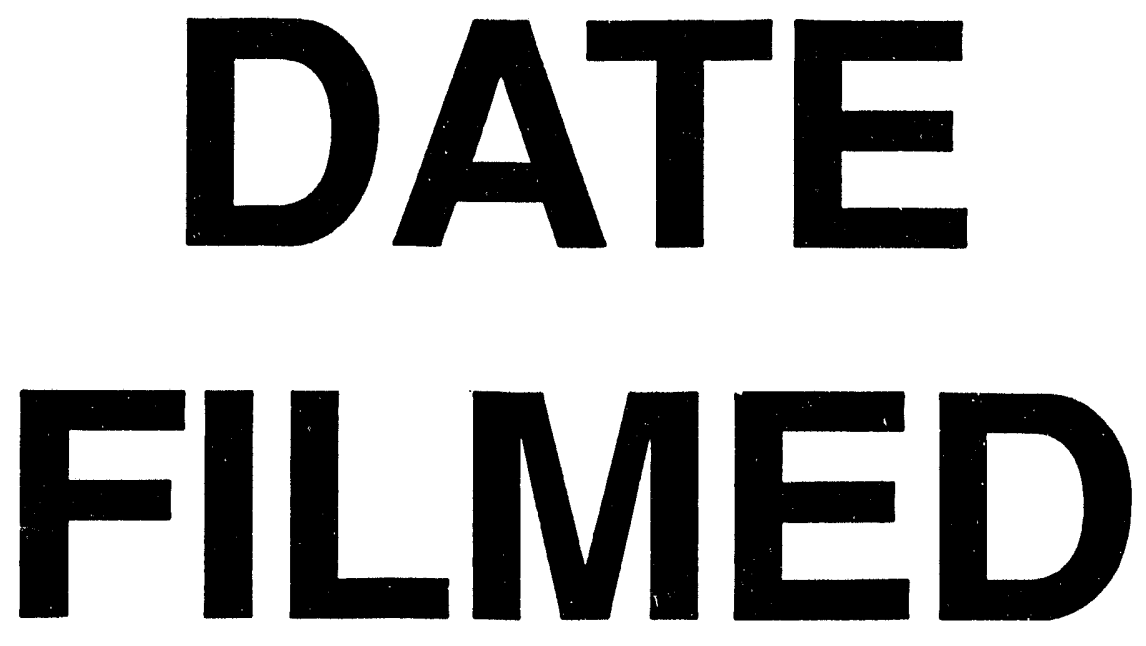

$10 / 24 / 94$
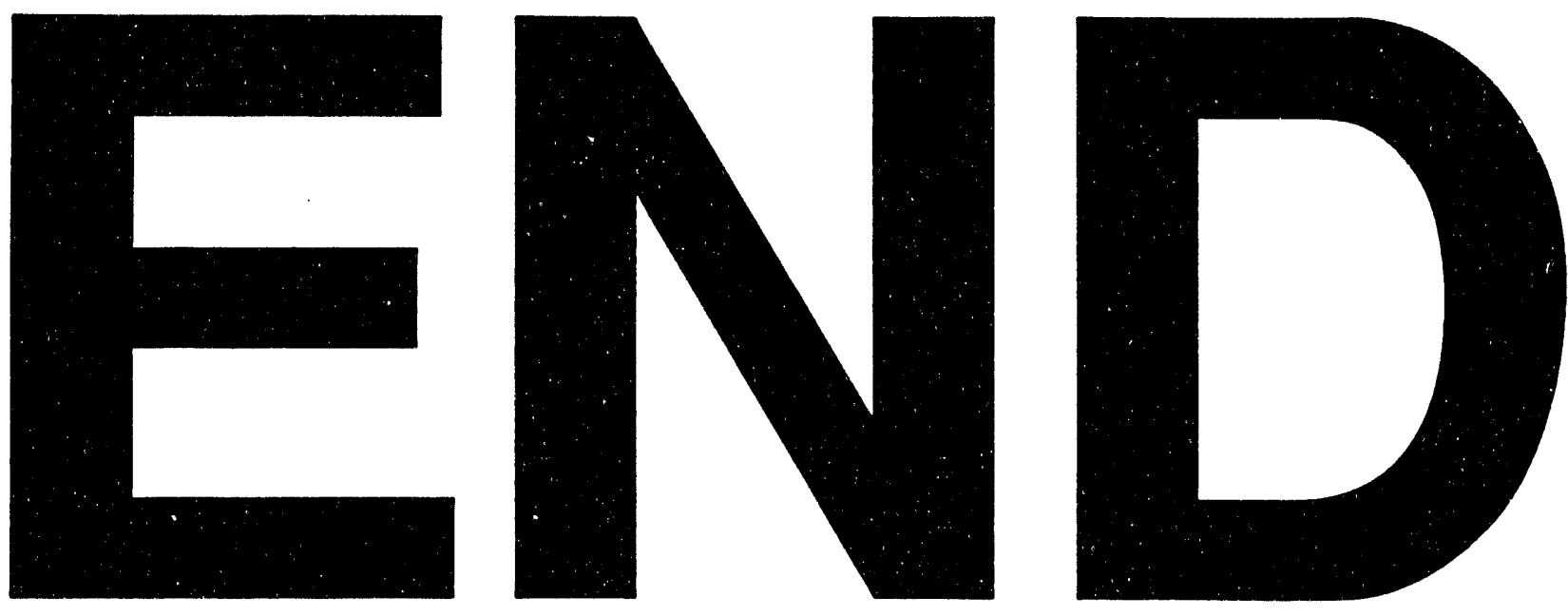
